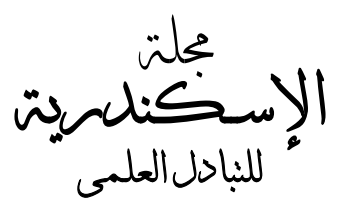

$r \cdot 17$

أكتوبر - ديسمبر

مجلد

أثر التوجيه الإداري على إدراك العاملين لجودة الأداء البيئي بالمسطح المائي وموارده بميناء الأسكندرية

محمود طلحه شعبان '، إيتسام السيد السيد، عاشور كامل عاشور '، هدي محمد عبد المنعم'، نور احن سعد حسن؟

إرثفاع التباين بين المبحوثين، وفي نفس الوقت إنخفاض نسبي في الارجة الكلية للتوجيــه الإداري، وإرتفـــاع التبــاين بـين

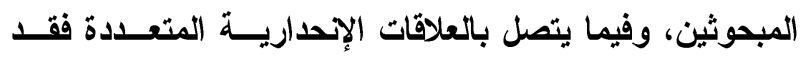
إتضح من النموذج الإتحداري أن المتغير المسـتقل الرئيسـي مسئول عن تفسير^, \&ه\% من التباين الكلي الممكن حدوثه في الارجة الكلية لإدراثك العاملين لجودة الأداء البيئي كمتغير تابع، وهذه المعادلة معنوية عند المستوى الإحتمالي ا ل ., .. الكثمات المفتاحية: التوجيه الإداري - الإدرالك- جودة الأداء

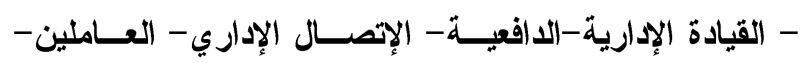
الموارد البيئية- المسطح المائي- ميناء الأسكندرية.

\section{المقدمة و المشكلة البحثبة}

تشكل البيئة البحرية كل مساحات المياه المالحـــة التــي تمثل كتلة متصلة بعضها البعض، منلاحمة الأجز اء ســو اء

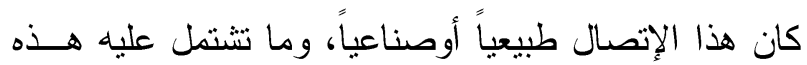
الكتلة من أوجه الحياة البحرية، وتلعب البحار و المحيطـات

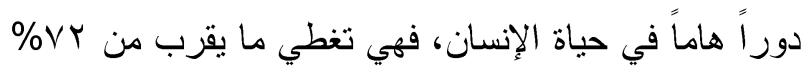
من سطح الأرض، كما أنها تســهم بنصــيب و افــر فـي المحافظة على التوازن البيولوجي للكرة الأرضية، ويضاف البف إلى ذلك أن البحار و المحيطات تمنل أهمية كبرى للإنســان فهي مصدر اً لغذائه، ومصدر اً للطاقة، ومورداً للمياه العذبة،
الماخص العربى

إستهدف هذا البحث بصفة رئيسية، دراسة أثـــر التوجيـهـ الإداري على إدرالك العاملين لجــودة الأداء البيئسي بالمســح المائي وموارده بميناء الأسكندرية، ويمكن تحقيق هذا الهــدف من خلال دراسة ستة أهداف فرعية. وقد تم تجميع البيانات البحثية بإستخدام إستمارة إبــتبيان بالمقابلة الشخصية، وتم أخذ عينة عشوائية بســيطة مقـــارها

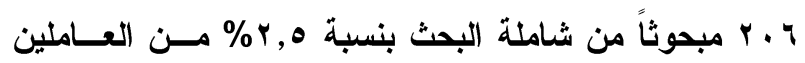

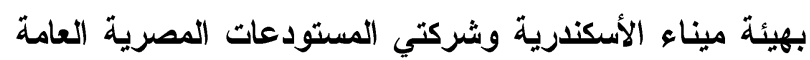
والأسكندرية لتداول الحاويات والبضائع، وقد تمثثـــ أسـاليب التحليل الإحصائي في النسب المئوية، والمتوســط الحســابي، والإتحر اف المعياري، وإختبار(ت)، ومعامل الإرثبــاط البسـيط، ومعامل الإرتباط المتعدد، و إختبــار(ف)، والإنحـــار المتعـدد،

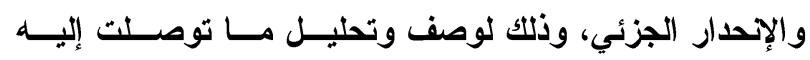

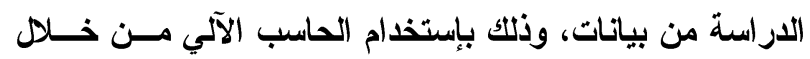

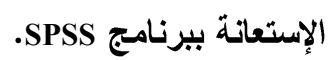
وتشير أهم النتائج البحثية إلى: إنخفاض المتوسطات الحسابية لمعظم المتغيرات المسـتقلة، مع إرتفاع التباين بين المبحوثين، كما إتضح إنخفاض الدرجات الكلية لإدر الك العاملين لجودة الأداء البيئي، وفي نفس الوقت

'قسم الإرشاد الزر اعي- كلية الزر اعة- جامعة الأسكندرية،

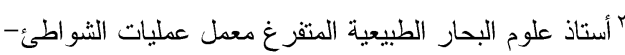

شعبة البيئة البحرية-المعهد القومي لعلوم البحار و المصايد،

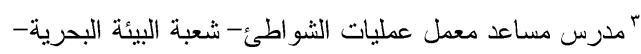
المعهز القومي لعلوم البحار و المصايد. مدئ.

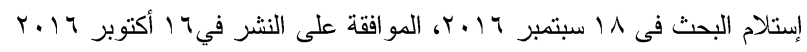


من ثلوث البيئة البحرية، وتدهور المنطقة الســـاحلية إنمـــا

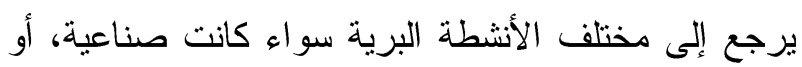

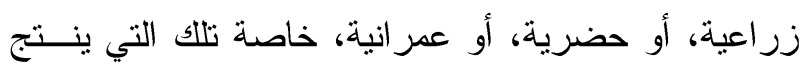

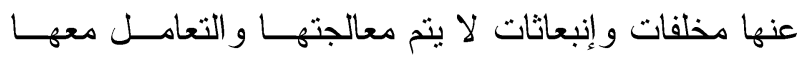

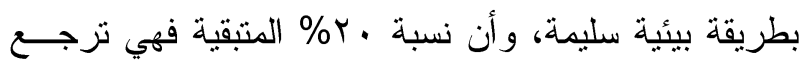

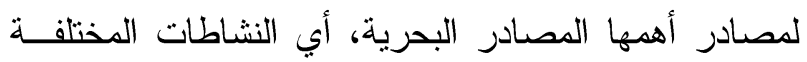
التي تتم في عرض البحر مثل الإستكثاف و التتقــبـ عـن النفط، و المعادن، و الغاز الطبيعي، و عمليات الصيد، و الثحن و التفريغ و النقل البحري، بجانب المخلفات و التسربات مـنـ

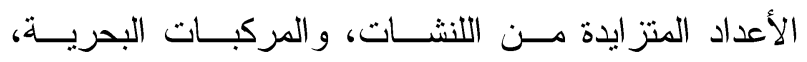

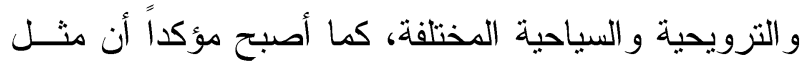

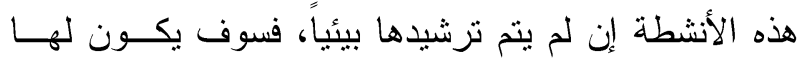

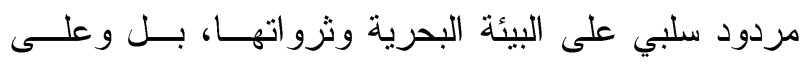
مختلف أوجه النشاطات التتموية الأخرى، و الإستثمار ولئ في

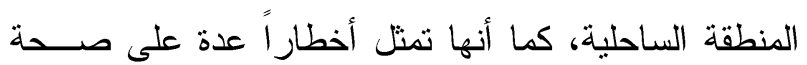
الإنسان و المناطق الساحلية و البحرية، (وزارة الدولة لشئون (a

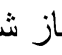
البيئ www.yemwn-nic.info/contents/Geog/6.pdf، ولذا كان حماية البيئة البحرية المصرية أمراً ضرورياً،

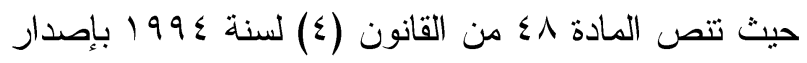
قانون البيئة على أن تهدف حماية البيئة المائية من التلــوث إلى تحقيق الأغر اض الآتية: أ- حماية شو اطئ جمهوريـــة مصر العربية ومو انيها من مخاطر التلوث بجميع صــوره

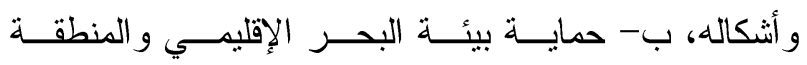
الإقتصادية الخالصة، ومواردها الطبيعية الحية وغير الحية وذللك بمنع التلوث أياً كان مصدره وخفضه و السيطرة عليه،

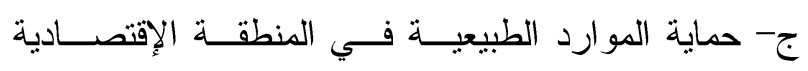
و الجرف القاري، د- التعويض عن الأضرار التــي تلحــق بأي شخص طبيعي أو إعتباري من جــر اء تلــوث البيئــة

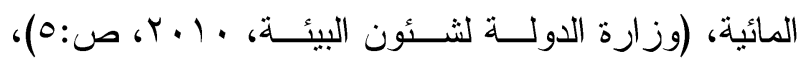
www.eeaa.gov.eg
ومصدراً للعديد من الثروات المعدنية، والنباتية المختلفــة، بالإضافة إلى أنو اع منباينة من الأحياء البحرية الحيو انيــة

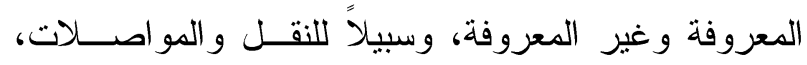

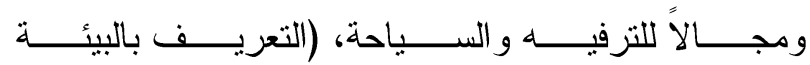
(البحرية)، ومن المسلم به أن تتباين الدول المختلفة في نصيبها من

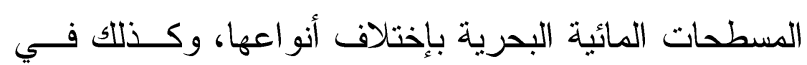
نصيبها من الأراضي الصحراوية، وتضـاريسها المتباينـــة،

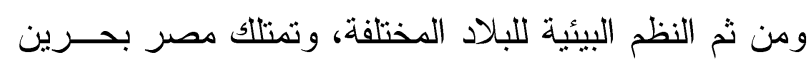
هما البحر الأبيض المتوسط، و البحــر الأحمــر، ويمــثلان لئن

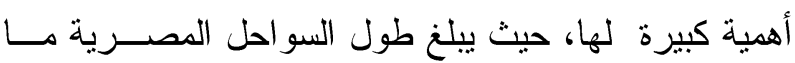
يقرب من ثلاثة آلاف كيلومنز ، منها حو الي ، 110

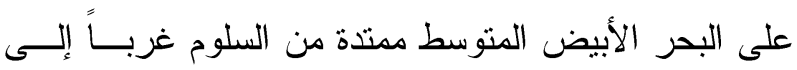

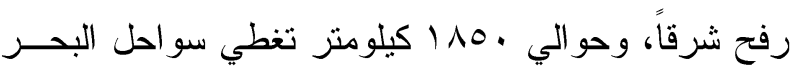
الأحمر المصرية، حيث بمثل منها الحوض الرئيسي للبحر الأحمر حوالي ( . . r ا كم)، ويمثل خليجي السويس والعقبة

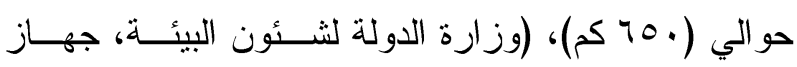

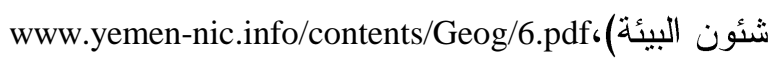
وتعتبر البيئة البحرية و المناطق الســاحلية لجمهوريــة

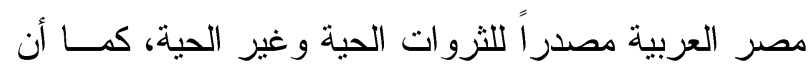

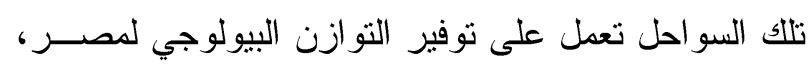

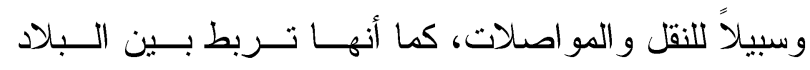
المختلفة، وهي نقطة جذب محورية للعديد من المشروعات

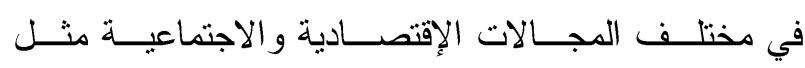
المشروعات الترفيهية والســياحية، ومشـروعات التـروة

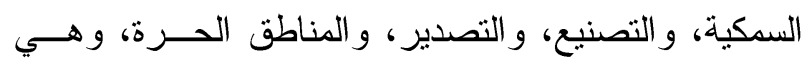

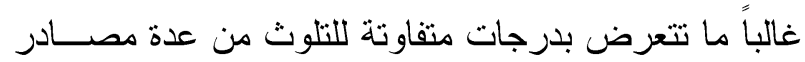
برية وبحرية. فلقد بات من الحقائق المعروفة - حسب ما أشارت إليه تقارير الأمم المتحدة 1990 GESAMP- وأكدت عليه الكثير

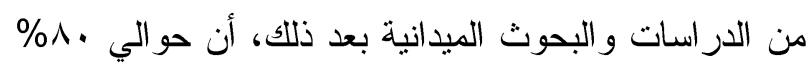


مجلة الإسكندرية للتبادل العلمى - (مجلد Vr العددء) أكتوبر - ديسمبر 1 ـ

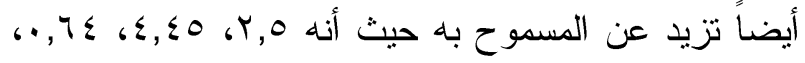

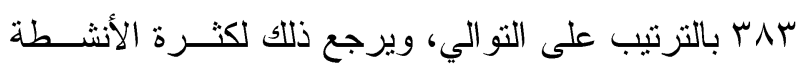
بالميناء مما يؤدي إلى زيادة نسبة التلوث في هذه المنطقـــة،

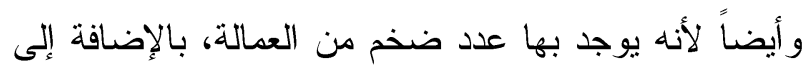

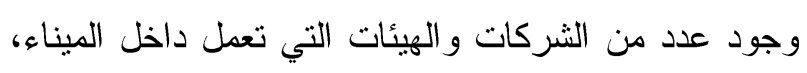

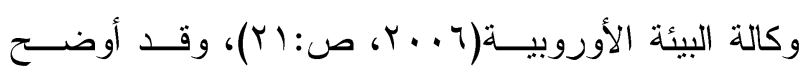

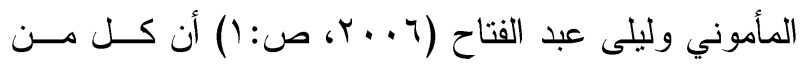
الميناء الغربية و الميناء الشرقية وخليج أبو قير على إمنـــداد

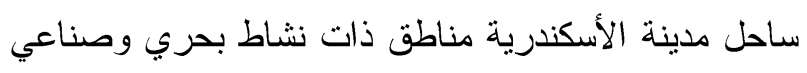
مكثف، وقد تم عمل تثقيبات قصيرة في الرواسب المتاخمة

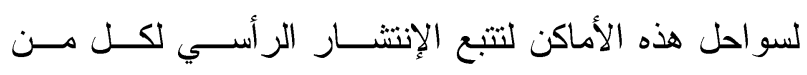

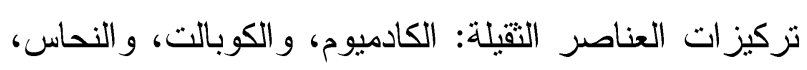
و الكروم، و النيكل، و الزنلك، و المنجنيز و الحديد، بالإضــافة

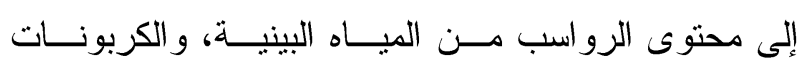

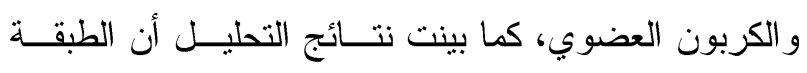

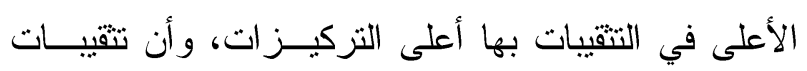

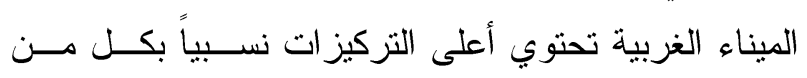
الميناء الشرقية وخليج أبي قير. ومن المسلم به أن العاملين في أي كيان يمثلون عمــوده الفقري، حيث يمثل خطأ العنصر البشري بشـــل مباشــر

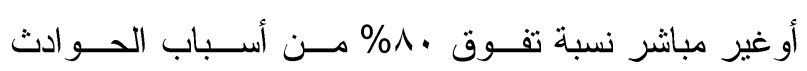

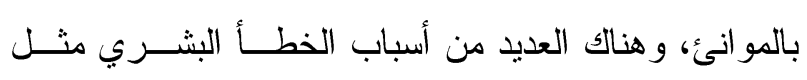
التعب و الإزهاق، وضعف الإتصال، و وعدم الوعي بالمخاطر

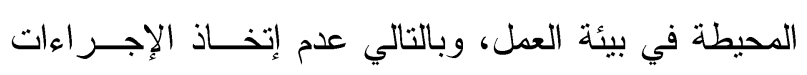

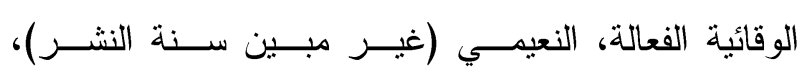
www.mubasher.info/news/2392929 ومما لا شك فيه أن الموانئ تعتبر من الأماكن التي تكثر

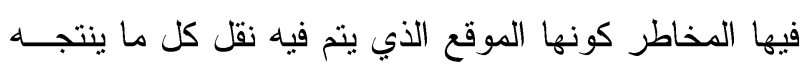
البلد وما يستورده من الخارج من مو اد وتجهيزات و غيرها،

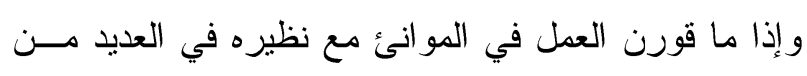

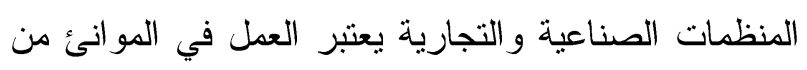
الأعمال الخطرة وذلك في ضوء الإعتبار ات التالية: اتساع
هذا ويوجد بمصر حو الي 10 ميناء تجاري أهمها ميناء

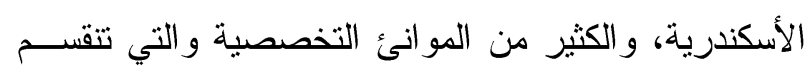

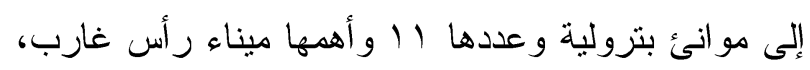

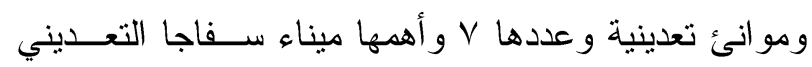

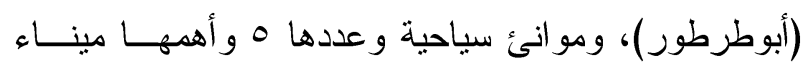

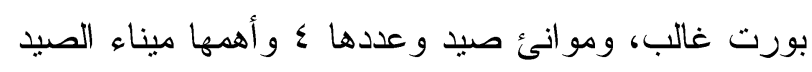

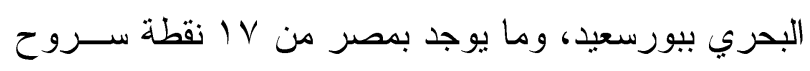

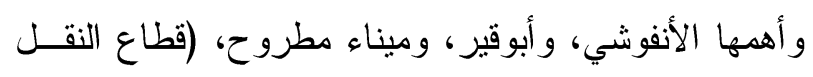
/\#http://www.mts.gov.eg،البحري) وتعاني الموانئ المصرية بالعديد من الملوثــات حيــث

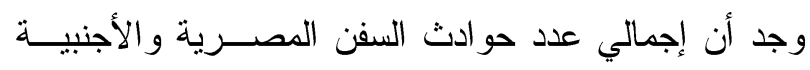

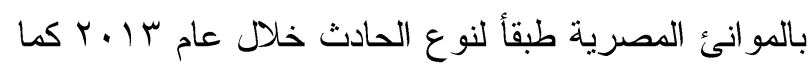

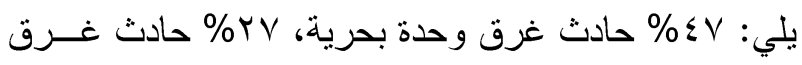

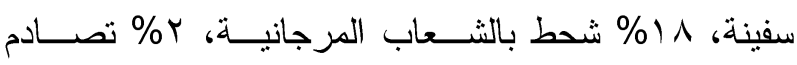

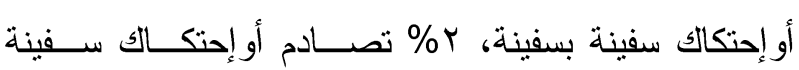

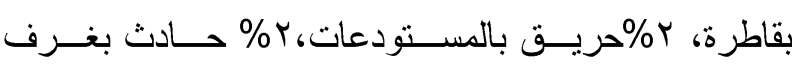

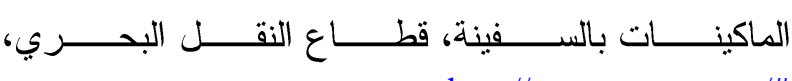
http://www.mts.gov.eg/\# ويعتبر ميناء الأسكندرية من أقدم و أعرق الموانئ حيث أنه كان همزة الوصل بين دول الثرق القديم وحوض البحر المتوسط، وهو أكبر الموانئ مساحة حيث تمر به أكثر مــن لهن

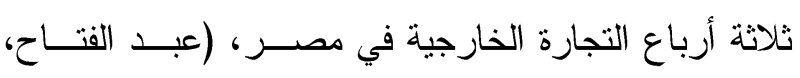

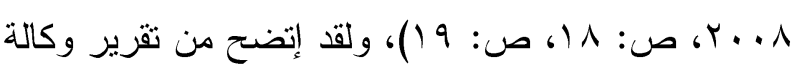

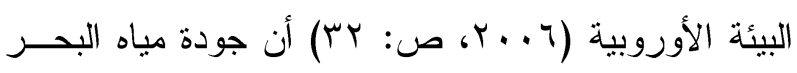

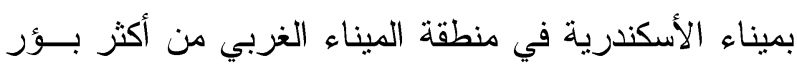
التلوث، حيث أن نسبة الأكسجين المذاب أقل من المســموح

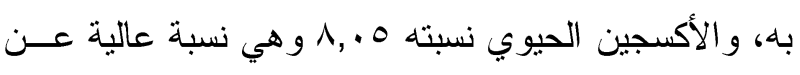

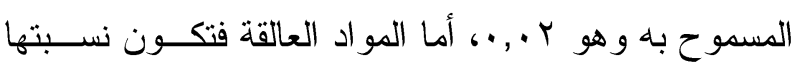
ع 10 و المسموح به هو بـ 1, وهو ما بدل على شدة التلوث

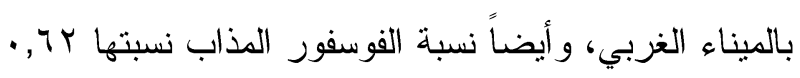
و هي أعلى من المسموح به وهو V •, •، وبالنسبة للمعـادن

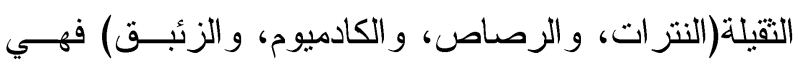


ويعد الاتصال الجيد بمثابة الدماء التي تجري في عروق

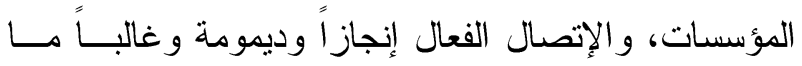
تكون مشكلة المؤسسات و إحدى عقباتهـــا الهامــة بإعتبـــار الإتصال الضعيف يقود إلى كوارث كثيرة، وبهذا فالاتصال وسيلة تعين الإدارة على تغيير سلوك العاملين حيث تتعرف من خلال هذه العملية على قدرات العاملين وكيفية أستقبالهم

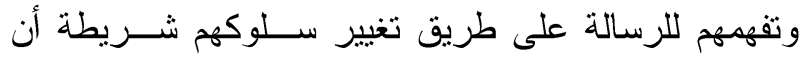
تكون عملية الإتصال فعالة وإيجابية، فمن خــلال عمليــة

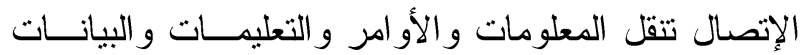
و القرارات من مستوى الإدارة العليا إلى مستويات التنفيـذ،

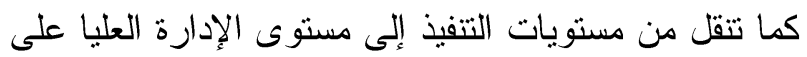

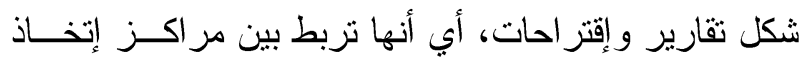
القرار ورسم السياسات في الإدارة ومر اكز التنفيـذ، لــذللك

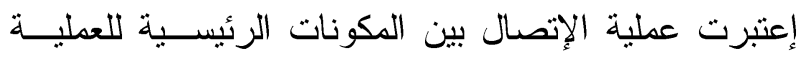

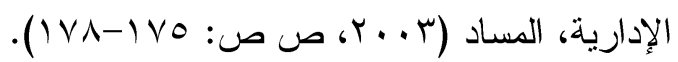
وتعتبر الدوافع من المتغيرات الرئيسية التي تلعب دوراً هاماً في سلوك الأفراد و السلوك التتظيمي بإعتبار أن الأفراد

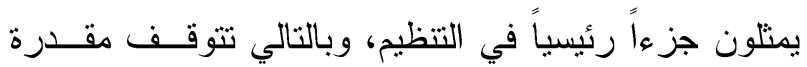
الإدارة في تحقيق أهداف المنظمة على توفر القدر الكــافي من الدوافع لدى الأفراد، وهذا يتطلب اللجوء إلــى القـــى الإدى

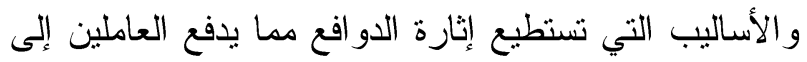

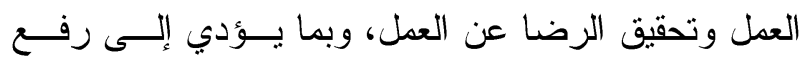

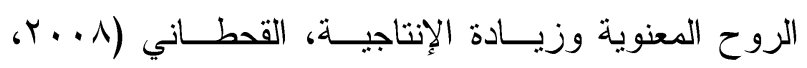

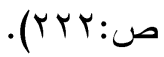

ويشكل إدر الك جودة الأداء البيئي للعاملين أهمية أساسية

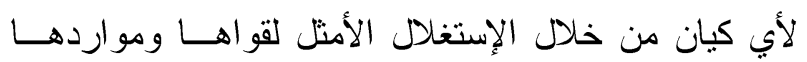

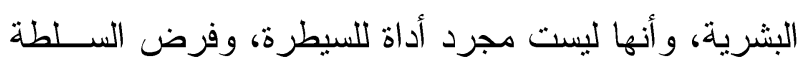
على العاملين، بل أداة للتشخيص المحكم و الموضوعي لأداء

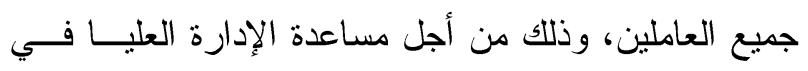

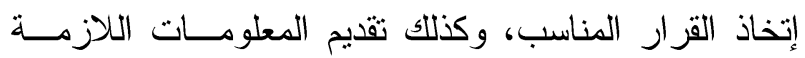
لإدارة الموارد البشرية لتمكنها من إدارة نللك الموارد بكفاءة
مساحة الميناء، وتتوع المو اد و البضائع، و الحاجة لإستخدام

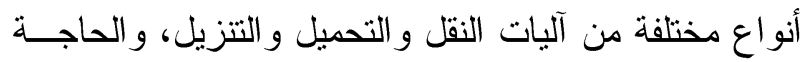
إلىى أكثر من مشرف سلامة مدرب ومؤهل، و إرتقاع عـدد

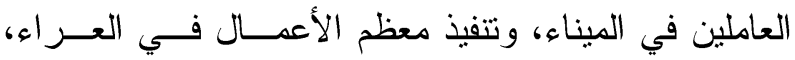

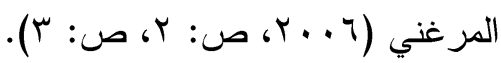
ويستلزم الأمر وضع إدارة جيدة تعمـلـل علــى تحقيــق

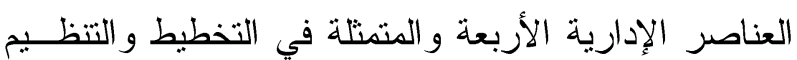
و التوجيه و الرقابة، حيث أن الإدارة في حد ذاتهـــا عمليــة إنسانية مستمرة تعمل على تحقيق أهداف محددة من خــلال الجهد البشري، و المنظمة ما هي إلا بناء مادي بجانب كونه

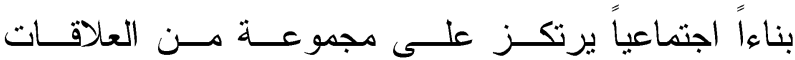
و الإتصالات و التفاعلات التي تأخذ شكل التعاون أو المنافسة أو الصر اع بين العاملين بالمنظمة من فئات اجتماعية منباينة

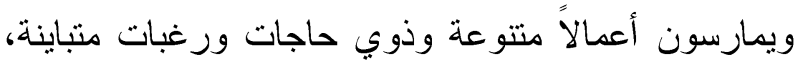

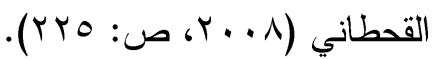
وترتبط فعالية المنظمة بمدى الجهد الذي يبذله الأفــر اد

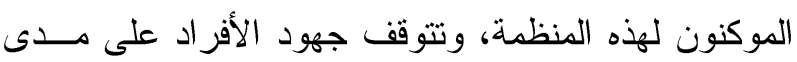
إحساسهح بالتكامل مع المنظمة و الإزتباط بأهدافها والــوعي بمضمونها، وحتى يمكن خلق فرق عمل متكاملة بالمنظمــة

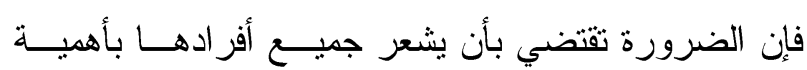

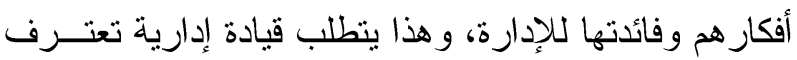
بجهود الآخرين وقادرة على تتسيق هذه الجهود وتوجيهــــا و على إثباع رغبات أفر اد المجموعات وحاجاتهم، القحطاني

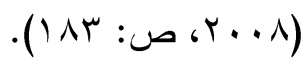
و القيادة الإدارية تمثل نوعاً متخصصاً من أنو اع القيــادة تستهدف الأساليب الإدارية التي تؤثز في سلوك الأفراد بما

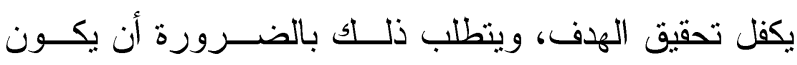

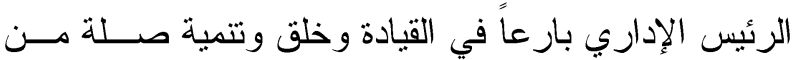
التبعية له و إتباع المرؤوسين و إستمالتهم، فالقيادة هنا هـي

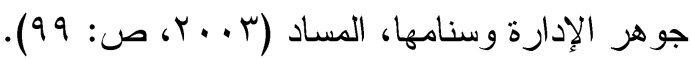


- التعرف على التوجيه الإداري للعاملين بميناء الأسكندرية

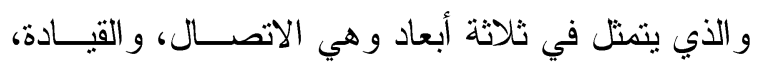

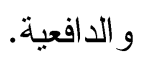
- التعرف علــى إدراك العـاملين لجـــودة الأداء البيئسي بالمسطح المائي ومو ارد بميناء الأسكندرية.

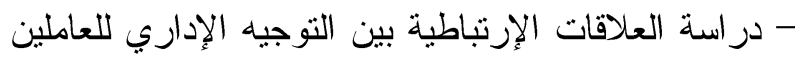

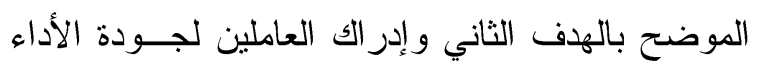

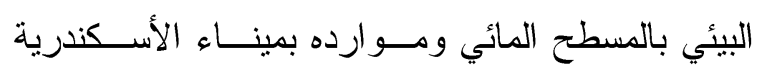
الموضح بالهدف الثالث. - دراسة العلاقات الثأثيرية بين التوجيه الإداري للعـاملين

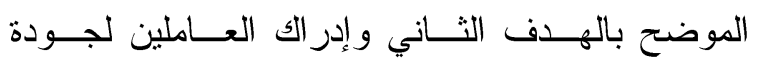

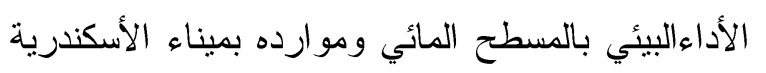
الموضح بالهدف الثالث. - التعرف على توقعات العاملين بميناء الأسكندرية لجـودة

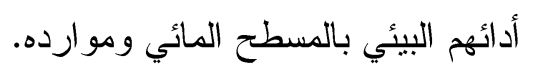

الأهمية النظرية و التطبيقية للبحث يدخل هذا البحث ضمن الجالات البحثية الإرشادية البيئية البحرية، فهو يقع ضمن إهنمامات العلوم الإدارية،

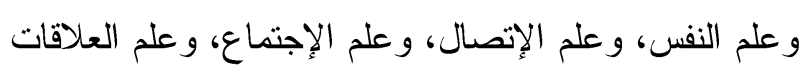

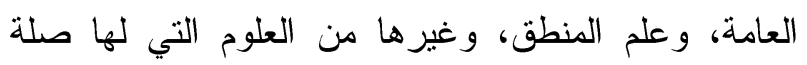
بسلوك الفرد والجماعة، ومما لاثكك فيه أن هنالك ندرة للبحوث في هذا الدجال الإرشادي البيئي، وفي نفس الوقت

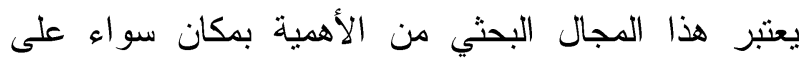

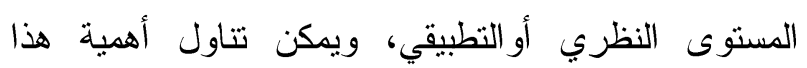
البحث النظرية و التطبيقية فيما يلي: البطئ

أولا: الأهمية النظرية:

إنطلاقاً من أن قيمة أي دراسة علمية لاتقاس فقط بمقدار

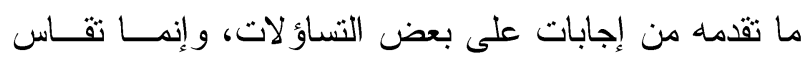

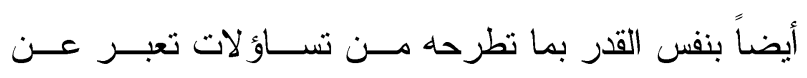

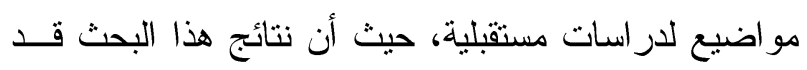

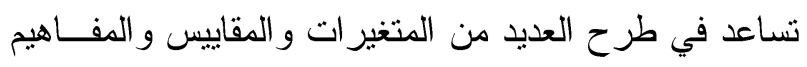

و إقتدار، ويتم ذلك من خلال تحسـين وتتظـيم و إبــتغلال

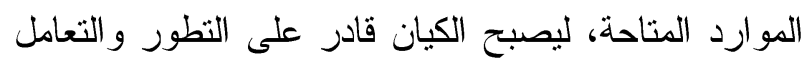
الجيد مع كل التغيرات التي تطر أ خلال إنجاز الأعمال. وفي ضو ء ما سبق من ضخامة البيئة البحرية مســاحة،

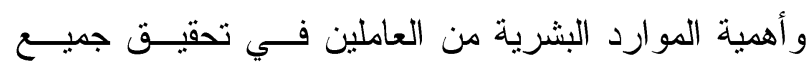

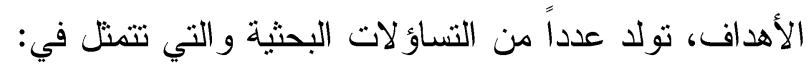
ما طبيعة وخصائص العاملين بميناء الأسكندرية و التي تتمتل

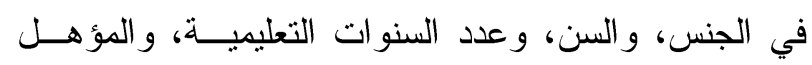

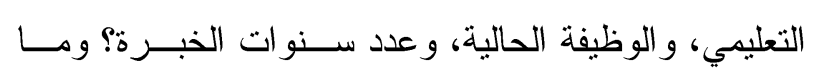

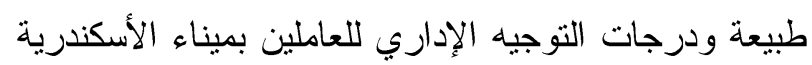

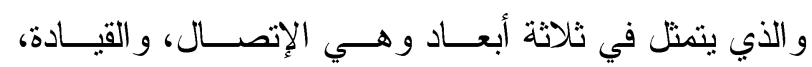
و الدافعية؟ وما طبيعة ودرجات إدر الك العاملين لجودة الأداء

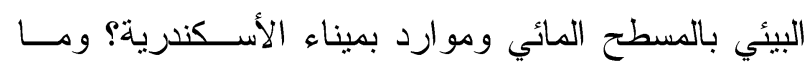

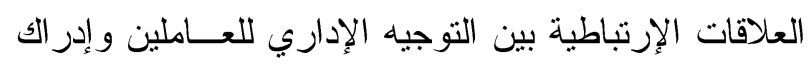

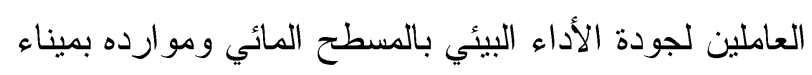

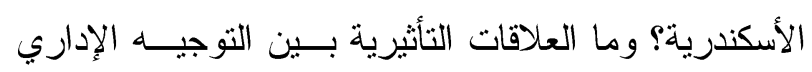

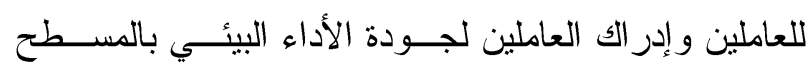

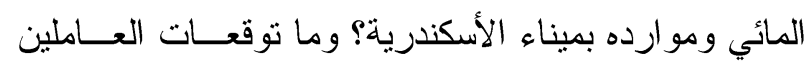

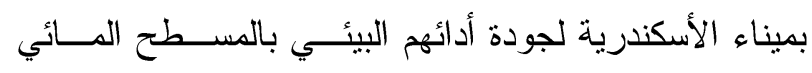

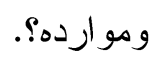

\section{الاهداف البحثية}

إستهذف هذا البحث بصفة رئيسية دراسة أثز التوجيه الإداري على إدرالك العاملين لجودة الأداء البيئي بالمسطح

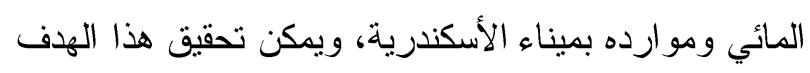
الرئيسي من خلال تحقيق الأهداف الفرعية التالية:

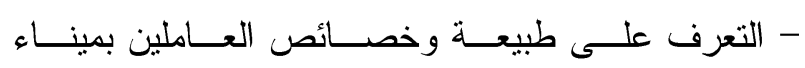

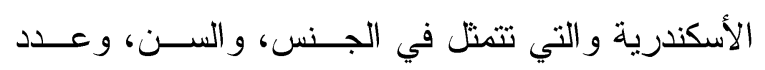

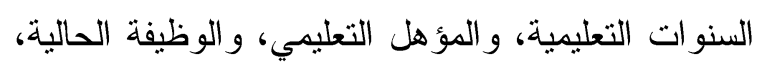
وعدد سنوات الخبرة. 
و لازال في كثير من دول العالم، ذلك المكان مسن الأرض

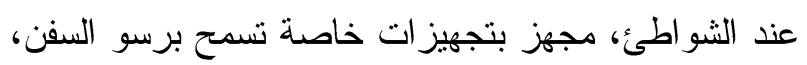

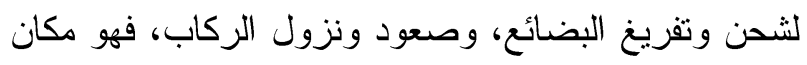

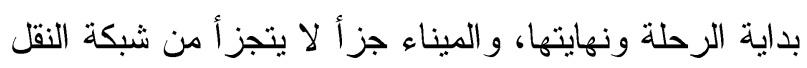

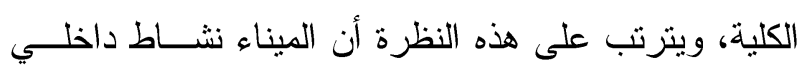

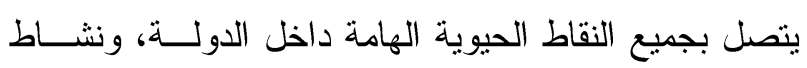

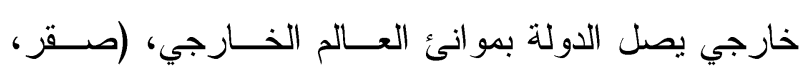
(ro: (r) (1990)

\section{التعريف بالبيئة البحرية:}

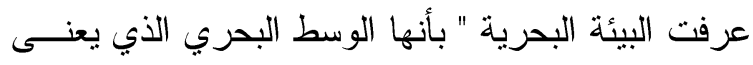

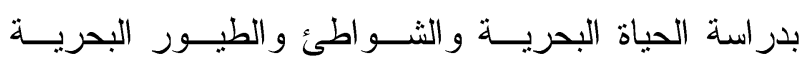

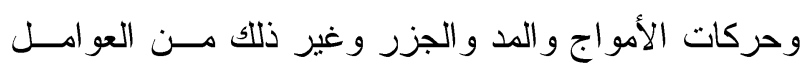

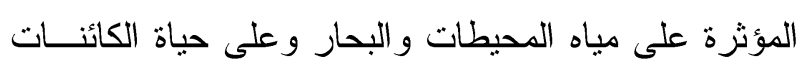
التي نعيش فيها وتتكون من ثلاث نظم أومحيطات أساســـة ولية وهي:

أ-المحيط المائي:إذ يعد الماء المكون الأساسي والأكبر في النظام الحيوي والذي يهيئ الظروف الملائمة للحياة

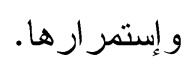

ب-المحيط الجوي: فالأرض مغلفة بجو يعمل على حماية

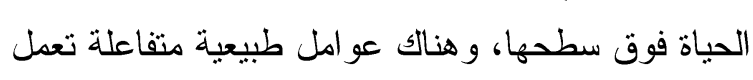
على حفظ هذا التوازن كالضغط، و الجاذبية، و الغازات،

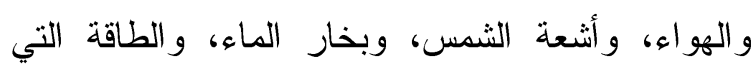
تمثل أبرز عوامل جو الأرض.

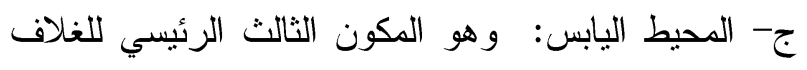
الحيوي، ويشمل الأجزاء الصلبة من الكرة الأرضية،

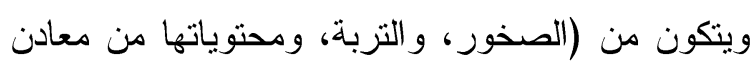

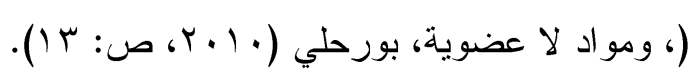
مفهوم التلوث البحري:

تتصف البيئة البحرية والتي تتشمل البحار و المحيطـات

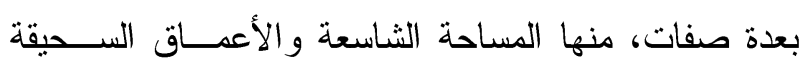

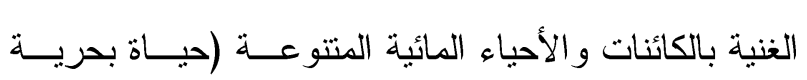

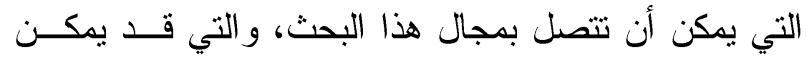
الإستعانة بها في الأبحاث المستقلية، و التي تقتح آفاقاً جديدة

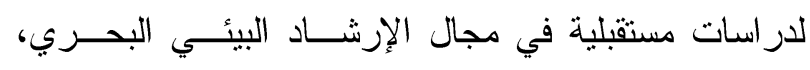

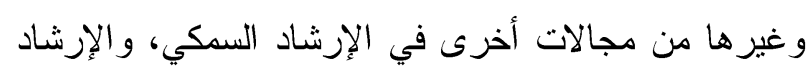

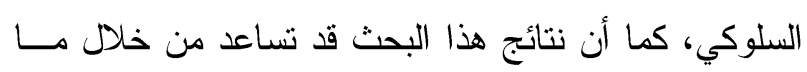

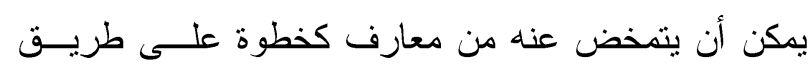
تنظير الإرشاد البيئي البحري في مجال جودة الأداء البيئي،

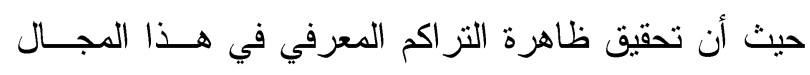

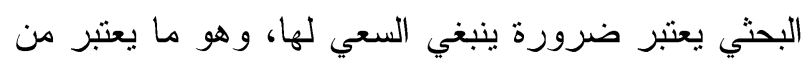

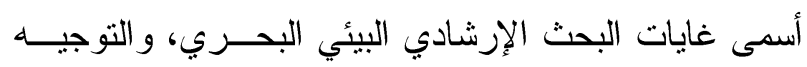

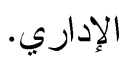

ثانياً: الأهمية التطبيقية:

تتبع أهمية هذه الدراسة فيما يتصل بالجانب التطبيقي من التهيه

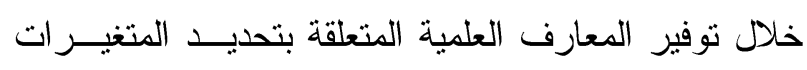

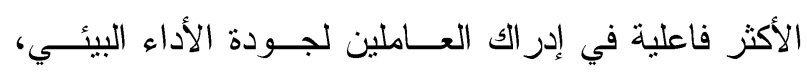

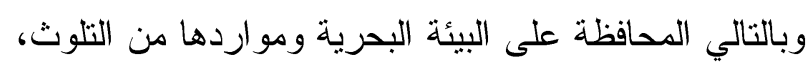

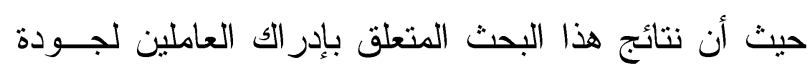

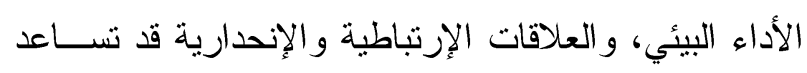

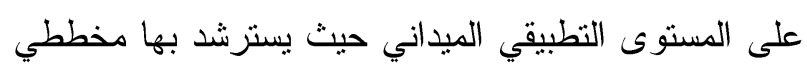

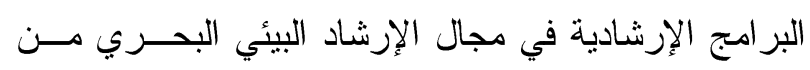

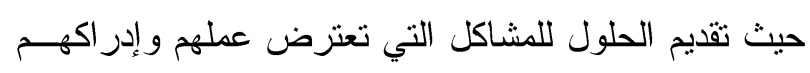

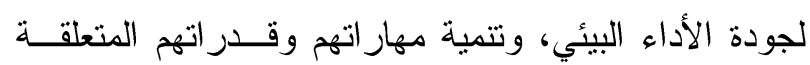
بجودة الأداء البيئي و التخطيط له، وتحديد الأنشطة التنريبية

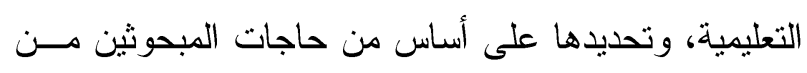

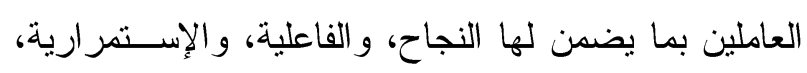

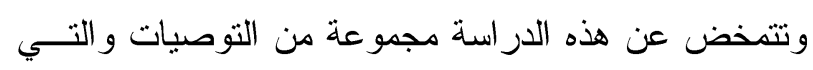
ينصح بنطبيقها في المستقبل.

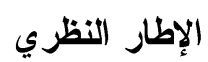
ماهية الميناء البحري: عرف الميناء تقليدياً بأنه المكان الذي يتم فيــهـ نـــاول

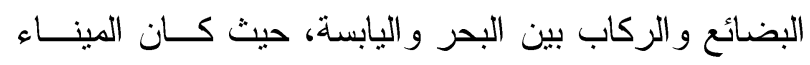


الخطأ البشري، مما يؤدي إلى تحسين الخدمة ورضــاء

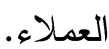

علاوة على ذلك فإن تكنولوجيا المعلومات والإتصالات يمكن تطبيقها في كل مر احل تتـــيل المـــوانئ، كـالإدارة

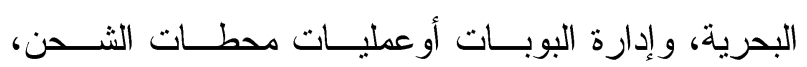

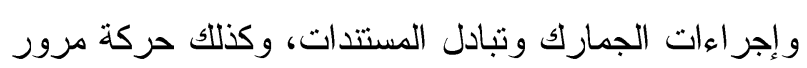
السفن، و التي تعتبر من الدكونات الأساسية للتنتغيل النـاجح

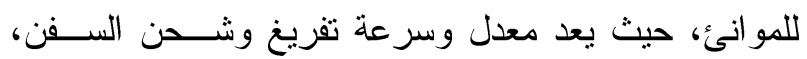
وزمن الإنظظار، و إثنغال المر اسي من العوامل التي تحسدد

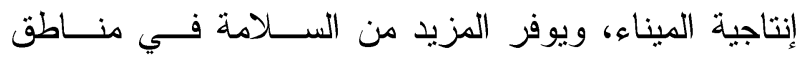

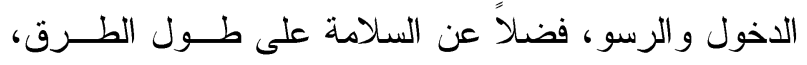

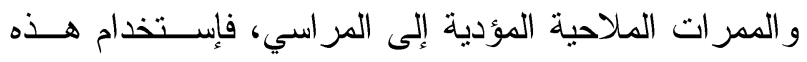

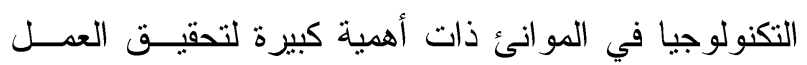

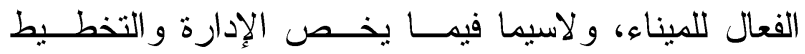

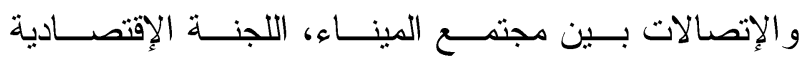

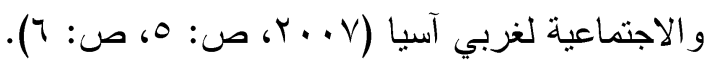
القيادة الإدارية:

وتعرف بأنها " محصلة التفاعل بين خصـــال شخصـية

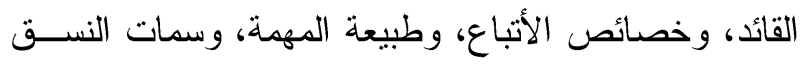

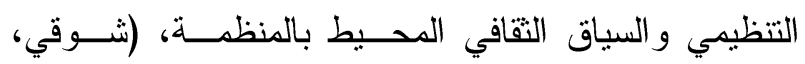

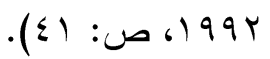

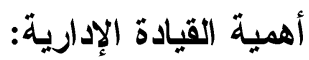
تبرز أهمية القيادة في الجانب الإنساني للإدارة بوضوح من خلال تتبع مسؤوليات القائد الإداري في مجال العلاقات

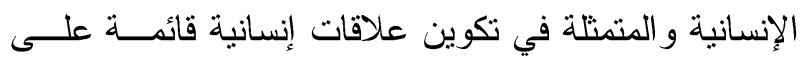

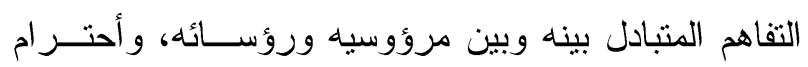

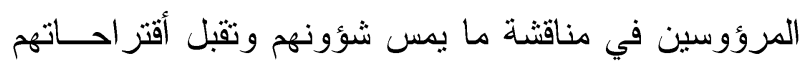
القيمة، و إثعار كل فرد بالتقدير المناسب لما ييذله من جهود

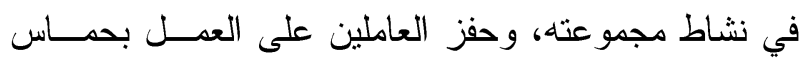

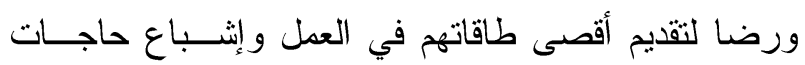
ومنطلبات المرؤوسين، (كنعان، ب99 19، ص: 1 • (1).
متتوعة )، ومياه دائمة الحركة تبعــاً للتيــارات الهوائيــة

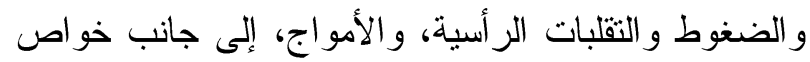
المياه المتمثلة في الملوحة الثديدة وإتصال البيئات البحرية بعضها البعض وغيرها من الخواص التي تجعل من البيئة

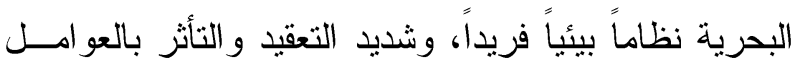

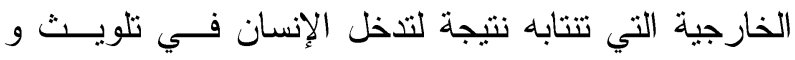

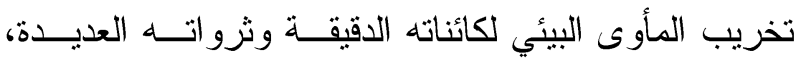

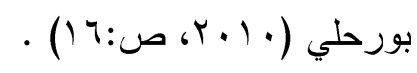

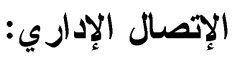
الإتصال عبارة عن "نثاط يشترك فيه طرفين أو أكثــر

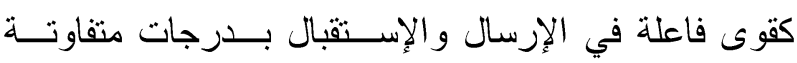

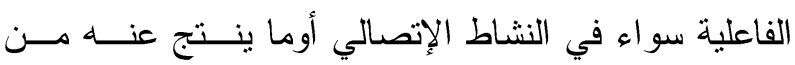

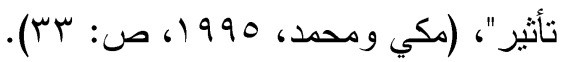

أستخذام تكنولوجيــا المعلومسـات والإتصــالات فــي إدارة

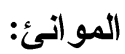

تستخدم تكنولوجيا المعلومات والإتصالات في الموانئ، لضمان الحصول على معلومات دقيقة وفي الوقت المناسب،

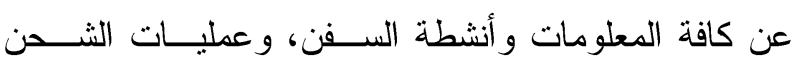

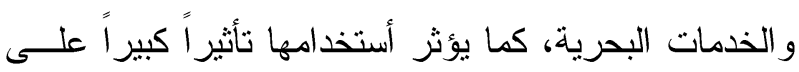
تسهيل التجارة، وتحقيق العديد من الفو ائد أهمها: - تحسين تكامل مجتمع الميناء عبر التبادل الإلكتروني للبيانات، والتي بدورها تؤدي إلى خفض الإجراءات

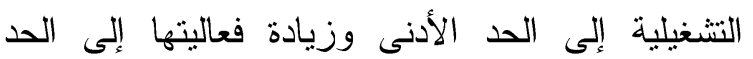
الأقصى. - تقليص زمن وتكلفة إجراءات السفن ولاسيما عمليات الثحن و التفريغ، بما في ذلك دخول وخروج السفن التهن وتخليص الثحنات، مما يؤدي إلى زيادة الإنتاجية و الربحية عبر الإستخدام الأمنل للمراسي والساحات، علاوة على زيادة عدد السفن المترددة على الميناء.

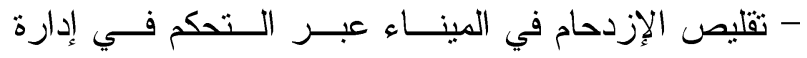

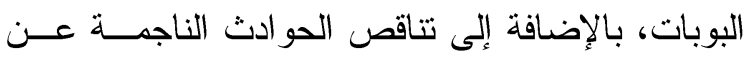


لقدرات ومو اهب العــاملين وتحفيــزهم لتحســين الجــودة

مفهوم الا(قعية:

الإنتاجية بشكل مستمر ودائم من خلال فرق عمل ولجـــان

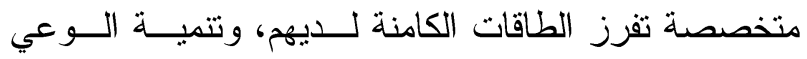
النقافي و الفني لدى العاملين، و معالجة كافــة المشـــاتلات و الصعوبات في حينه والتوصل إلى أسباب وقوعها و إتخاذ

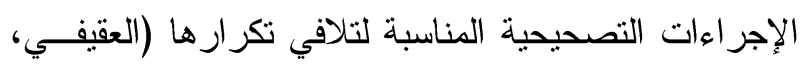
Www.q8ship.com (T...

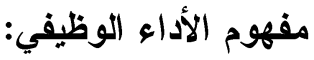

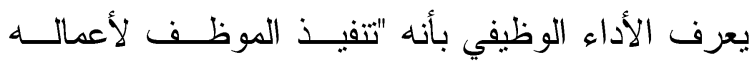

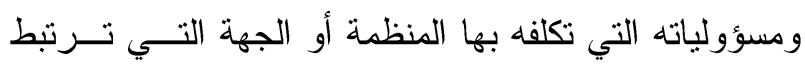

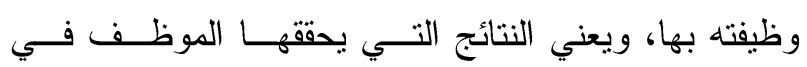

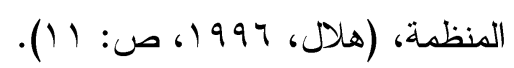

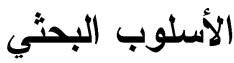

\section{التعريفات الإجر ائية البحثية}

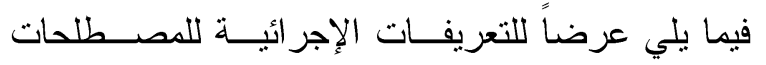
و المفاهيم الرئيسية الو اردة بهذه الدر اسة:

التوجيه:

ويقصد به في هذا البحث "إرشـــاد المرؤوســين أثتـــاء تتفيذهم للأعمال من خلال ثلاثة أبعاد رئيسية وهي الإتصال و القيادة و الدافعية، ويتم قياس هذا المتغير بالتقــدير الــذاتي بالدرجات من (1- • () لكل عبارة، من خلال مقياس مكون

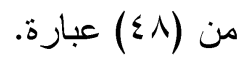

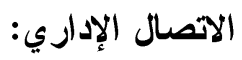
ويقصد به في هذا البحث درجات وجود مشاركة بـين الإدارة العليا و العــاملين فــي إحـــداث عمليــات التغييــر

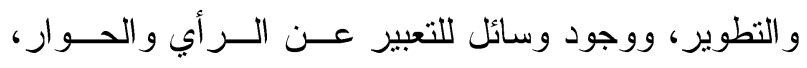

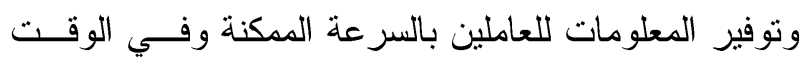
المناسب، وتحديث وتطبيق مر احل الإدارة الإلكترونية فـي

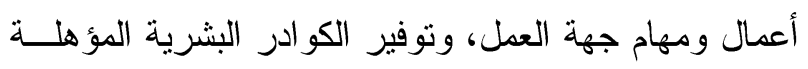
لإستخدام تقنيات الإتصال، و عدم وجود تبــاين فــي إدراك ولك
يمكن تعريفها أيضاً بأنها "حالة داخلية أو إستعداد داخلي،

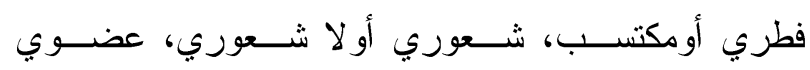
أو إجتماعي أونفسي، يثير السلوك، ذهنياً كــان أوحركيــا،

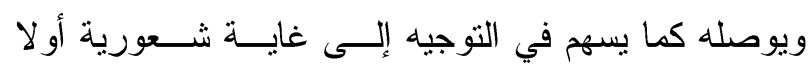
شعورية، فمن الدوافع ما هو فطري وما هو مكتسب، ثم ما في هو شعوري وما هو لا شعوري"، سيكولوجية الدافعية، www.onefd.edu.dz/infpe/cours\%20pdf\%201 mef/...p df/Psycho\%20env1\%20def03.pd..

الإدر (أك:

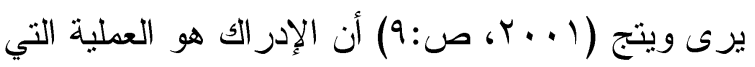

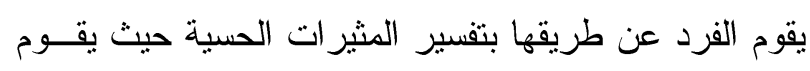
بتسجيل المثيرات البيئية، بينما يضطلع الإدراك بتفسير هذه

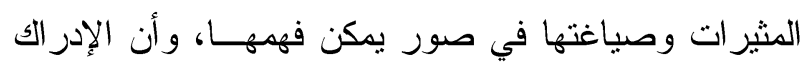
في معظمه دالة للخبرة بمعنى أنه سلوك متعلم وتتشير نتائج البحوث إلى أن الفرد الذي تحدد خبراته الإدر اكية أو تهمل

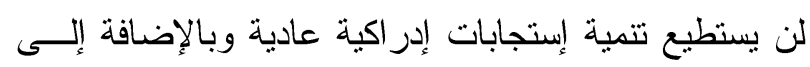

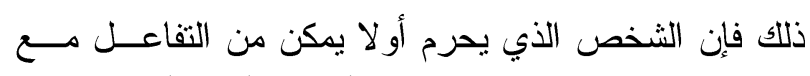

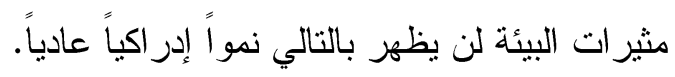

الجودة:

يعرفها جوران أنها الملائمة للإستخدام، ويقصد بذلك أن

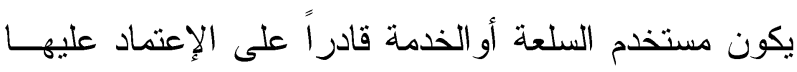

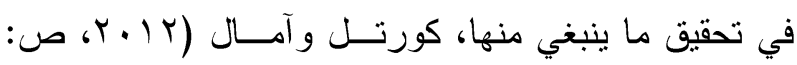

. (1)

تطبيق الجودة الثاملة في الموانئ: ينتج عنه زيادة فرص المنافسة و إستقطاب المزيد من التجارة البحريــة، وزيــادة الفعالية، ورفع الكفاءة وزيادة الإنتاجية، وسرعة الإســتجابة

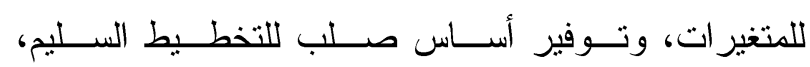

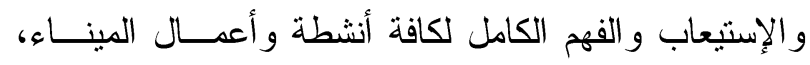
و إتاحة الفرصة للتغيير والتطوير المستمر لعمليات الموانئ والئ

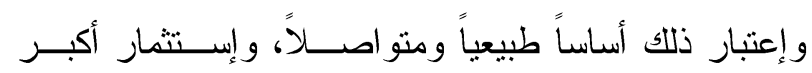


بالتقدير الذاتي بالدرجات من (1- (1) لكل عبــارة، مــن خلال مقياس مكون من (1/) عبارة. المتغير ات البحثية يتتاول هذا الفصل عرضاً للمتغيرات البحثية التـي تــــ تحديدها في ضوء أهداف البحث، وقد نم الإستعانة في ذللك

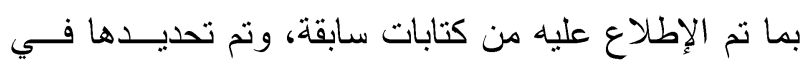
ضوء ما أمكن الإطلاع عليه من المراجع و الكتابات العلمية

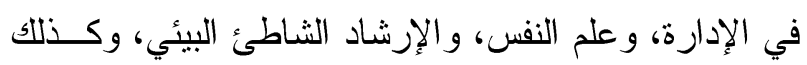

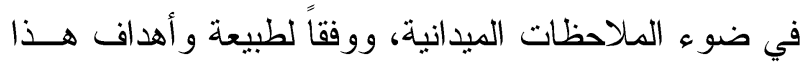
البحث، مجموعة من المتغيرات البحثية على النحو التالي:

أولاً: المتغير ات المستقلة: Independent Variables قامت هذه الدراسة على متغير مستقل وهـــو التوجيـهـ الإداري وهو يتكون من ثلاث محكات هم: - الإتصال الإداري ويتمثل في المشاركة في تتمية الإتصال،

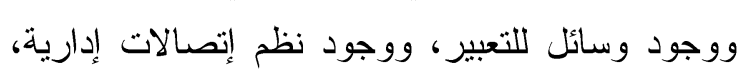

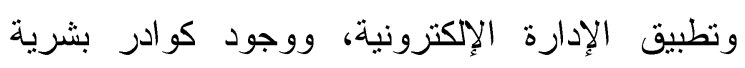
مؤ هلة.

- القيادة الإدارية ويتمثل في التفويض الإداري، ونمط القيادة الإدارية، و الإهتمام بالتحديث و التنمية.

- الافعية وتتمثل في المشاركة في أعمال المنظمة، ونوفير الحافز المادي و المعنوي، والرضا عن بيئة وطبيعة العمل.

ثانياً: المتغير التابع: Dependent Variable قامت هذه الدر اسة على متغير تابع مركزي و احد وهـــو إدر الك العاملين لجودة الأداء البيئي بالمسطح المائي وموارده بميناء الأسكندرية.

\section{الفروض البحثية}

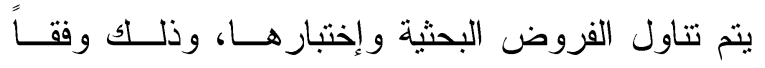

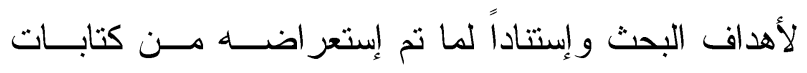

و إختلاف فهمه للأوامر و التعليمات، ويتم قياس هذا المتغير

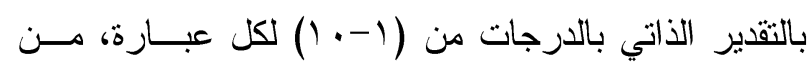

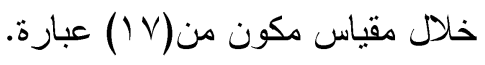

القيادة الإدارية:

ويقصد بها في هذا البحث درجات تفــويض المــديرين العاملين في بعض ســلطات إتخــاذ القــرارات، وأهتمـــام

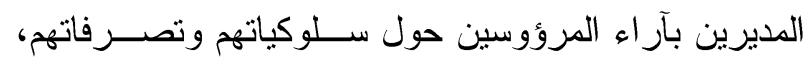

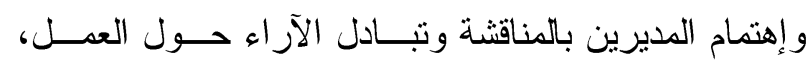

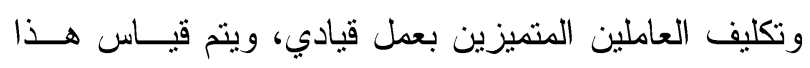

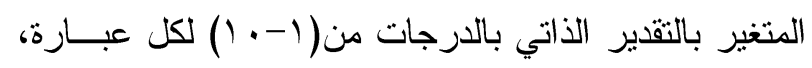
من خلال مقياس مكون من (7 (1) عبارة.

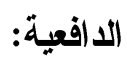

ويقصد بها في هذا البحث بأنــهـه مجموعــة الحاجــات

و الرغبات غير المشبعة أوناقصة الإشباع و التي يتعرض لها المبحوث أثثاء عمله وتؤثر على تفكيره و إدر اكه وســلوكه

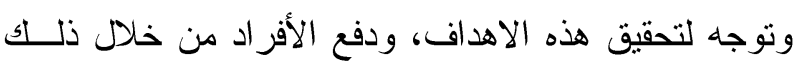
الإشباع إلى المشاركة في أعمال المنظمة، وتحقيق الإنجاز

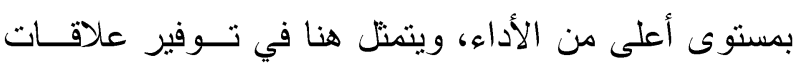

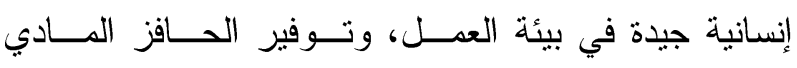
و المعنوي للمبحوثين، و الرضا عن بيئة وطبيعة العمل، وينت قياس هذا المتغير بالتقدير الذاتي بالدرجات مــن (1- (1) لكل عبارة، من خلال مقياس مكون من (0) عبارة. إدرالك جودة الأداء البيئي للعاملين بميناء الأسكندرية: ويعرف إدر الك جودة الأداء البيأــي للعــاملين بمينـاء

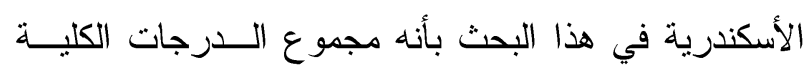

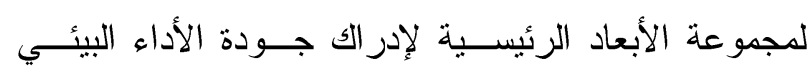
و المتمثلة في عناصر الأداء الوظيفي، ومحددات ومعـايير الأداء الوظيفي، وتقييم الأداء الـــوظيفي، ومســتوى تــأثنير

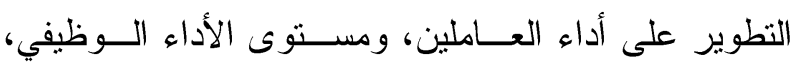
ومنظومة جودة العمل داخل الميناء، ويتم قياس هذا المتغير 


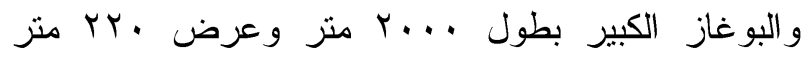

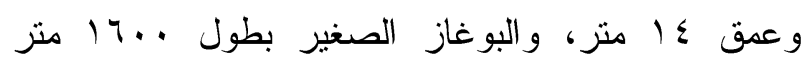

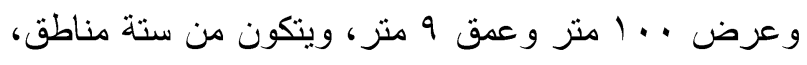

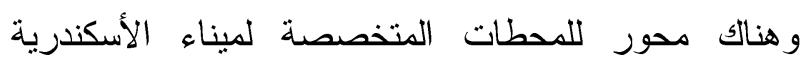
وتتمنل في: محطة الركاب البحرية، ومحور محطات الحبوب بميناء الأسكندرية، ومحور محطات البترول بميناء الأسكندرية، ومحطة الفحم، ومحطة المواشي، ومحطة الإشار ات القمرية، ومحور محطات الحاويات. ثانياً: شركة المستودعات المصرية العامة: - لقد تأسست شركة المستودعات المصــرية العامــة فـى سـى الخامس عشر من ديسمبر عام . 1943

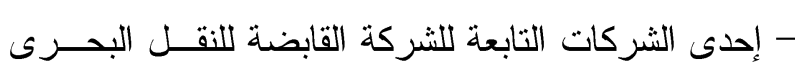

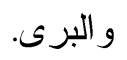
- تدير الثــركة مجموعــة مــن المخــازن و الســاحات كات

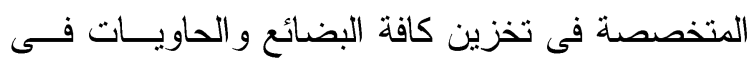

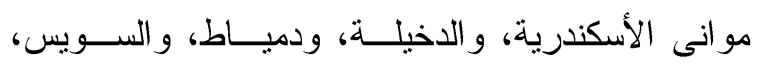

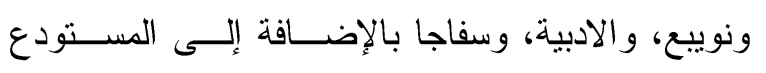

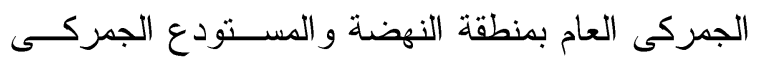

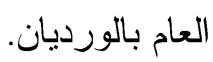
- تمتلك الثركة أسطول ضخم من الثاحنات و الحاويــات لنقل البضائع لأى موقع بجميع إنحاء جمهورية مصــر فئر العربية.

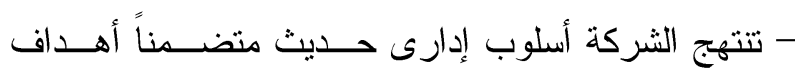

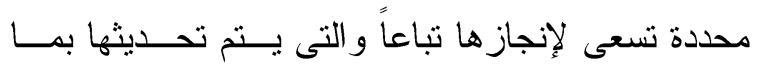
يتماشى مع كافة الظروف الخارجية المحيطة. - الشركة لديها مو ارد بشرية مميزة فى كافة الأنشطة لتكفل

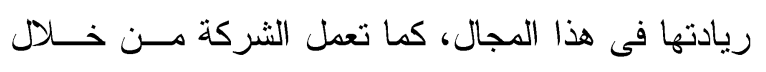

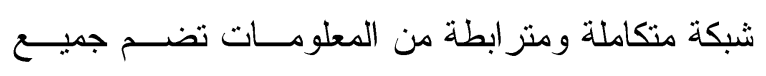
فروع الثركة و إدارتها و التى تساعد الإدارة العليا على منى

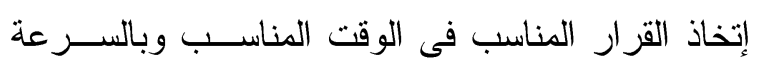

وبحوث ودر اسات سابقة، ومــا أمكـن إستخلاصــهـ مــن تعميمات، فقد تمنلت الفروض النظرية لهذا البحث فيما يلي: أولاً: توجد علاقة إرتباطية مغزوية بين كل من التوجيه الإداري للعاملين بميناء الأسكندرية و الذي يتمنل في ثناتـــة أبعاد و هي الإتصال، و القيادة، و الدافعية كمتغير ات مســتقلة

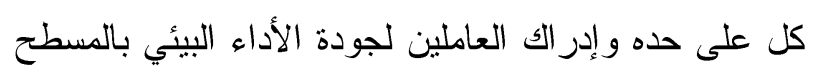
المائي وموارد بميناء الأسكندرية كمتغير تابع، ويتم إختبار هذا الفرض في صورته الصفرية.

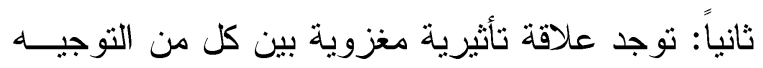
الإداري للعاملين بميناء الأسكندرية و الذي يتمثل في ثلاتـــة أبعاد و هي الإتصال، و القيادة، و الدافعية كمتغير ات مســتقلة

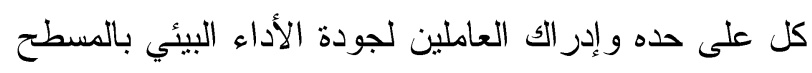
المائي وموارد بميناء الأسكندرية كمنغير تابع، ويتم إختبار هذا الفرض في صورته الصفرية. منطقة البحث أولاً: ميناء الأسكندريـة: تقع الإسكندرية عند الطرف الغربى لالتا نهر النيل بين البحر الأبيض المتوسط وبحيرة مريوط، وتعد من حيث أهميتها ثنانى مدينة فى جمهورية مصر العربية و الميناء الرئيسي لها وتمر بها أكثر من ثلاثة أرباع التجارة الخارجية للبلاد ويوجد بالإسكندرية ميناءان أحدهما يقع جهة الثرق والآخر جهة الغرب ويعرف الأول بالميناء الثرقي و الثاني بالميناء الغربى يفصل بينهما شبه جزيرة على هيئة حرف (T) و الميناء الثرقي ضحل لا بستخدم فى الملاحة بينما يؤلف الميناء الغربى من الناحية الفعلية ما اصطلح على تسميته بميناء الإسكندرية ويحد الميناء الخط الوهمى

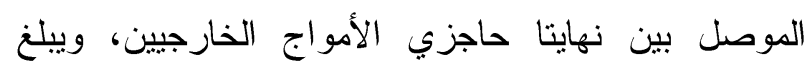
المسطح المائي للميناءی,7 كمَ'، والمسطح الأرضي 17

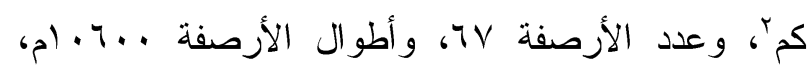

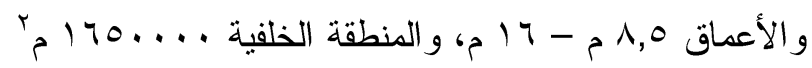
شاملة المباني الإدارية و المخازن، وعدد المحطات: .ب، 
مجلة الإسكندرية للتبادل العلمى - (مجلد Vr العددء) أكتوبر - ديسمبر 1 ـ

أسلوب جمع البيانات وتحليلها

تم تصميم إستمارة إستنيان بالمقابلة الثخصية لكي تحقق

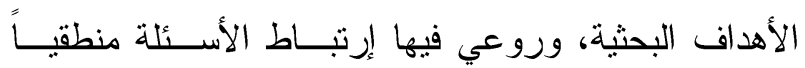

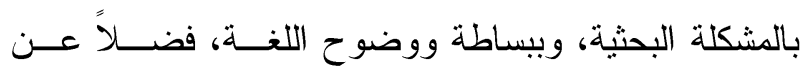
تسلسلها المنطقي، مما إستدعى الرجوع إلـى الكثئــر مـنـن

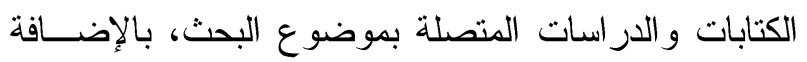

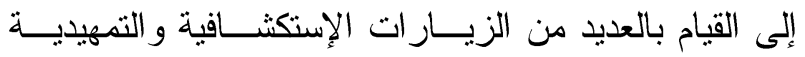

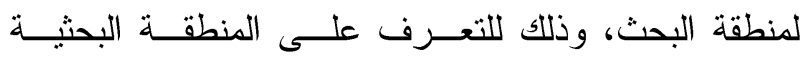
و العاملين بها، و على الثركات التي تعمل بها و أكثر تـأثيراً على البيئة البحرية.

وبناءاً على ذلك نم تصميم إستمارة البحث، و التي تضمن البحنة

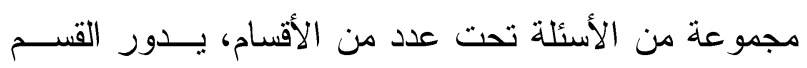
الأول منها حول بعـض الخصن الخصــائص الميــزة للعـاملين

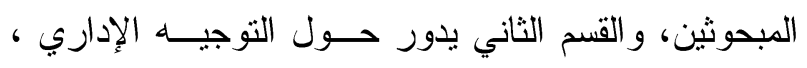
و القسم الثالث يدور حول إدر الك العالملين لجودة الأداء البيئي

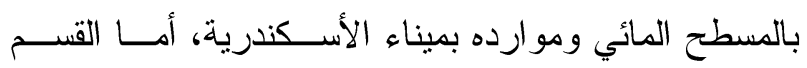

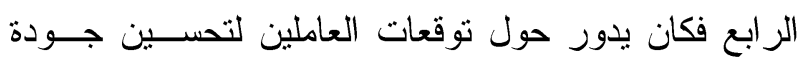
الأداء البيئي في المسنقبل.

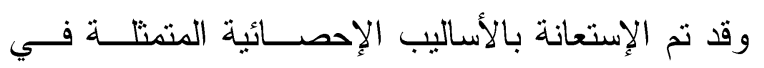
النسب المئوية، و المتوسط الحسابي، و الإنحراف المعياري،

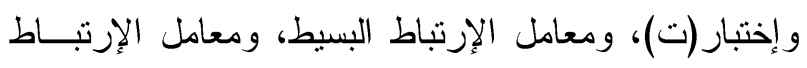

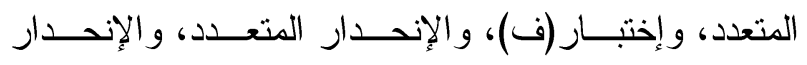

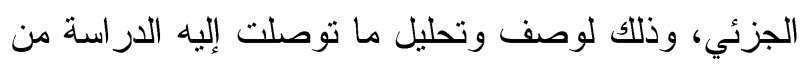
بيانات، وذللك بإستخدام الحاسب الآلي من خلال الإنــتـعانة

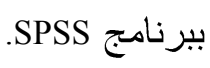

\section{النتائج البحثية}

سيتم عرض ومناقثة النتائج البحثية المتعلقة بكـلـ مــن

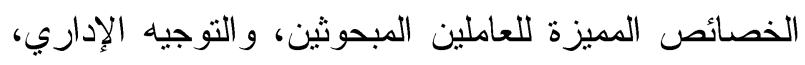

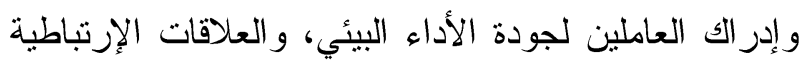

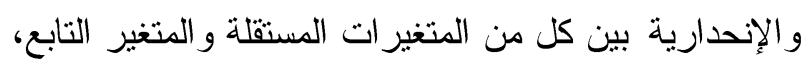
وتوقعات العاملين توقعات العاملين بميناء الأسكندرية لجودة
- الثركة حاصلة على شهادات النو افق مـع المو اصــفات القياسية الدولية.

ثنالثاً : شركة الأسكندرية لتداول الحاويات و البضائع:

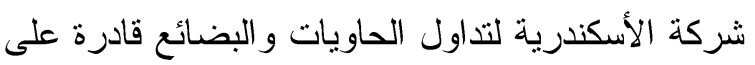

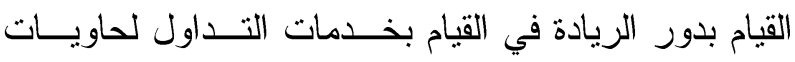
التجارة الخارجية وتجارة تعقيب الثحن وتقـديم خـدمات

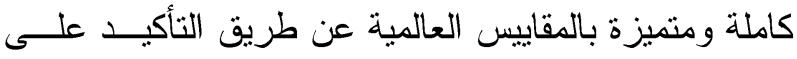

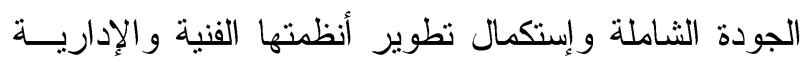
و المعلوماتية و الإجتماعية مما يؤدي إلي زيادة القدرة المالية

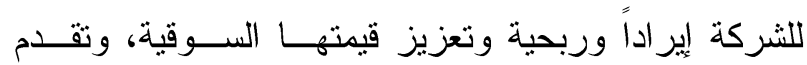
الثركة تثكيلة منلى من خدمات الثندن و التقريغ و التخزين السريعة والآمنة وبتعريفة تتافسية لتداول حاويات التجـارة

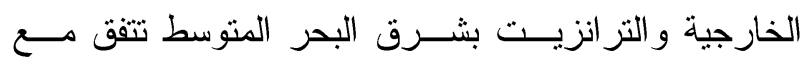
معايير الأداء السائدة في الصناعة. شاملة البحث وعينته

تتمتل شاملة هذا البحث في جميع العاملين بهيئة مينـاء الأسكندرية وعددهم 3946، وكــللك مجموعــة العـاملين بشركتي المستودعات المصرية العامة وشركة الأســكندرية لتنداول الحاويات و البضائع و عددهم كالتــالي 1244 :؛ 3945 على الترتيب، ونظراً لكبر إنتشار شاملة البحث بهيئة ميناء

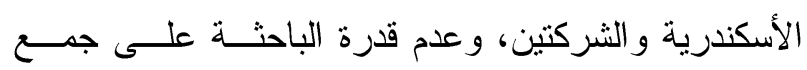
البيانات من الثاملة نظراً لكبرها، فقد تم أخذ عينة عشور الئية بسيطة وتتمتل في مجموعة مـن العـاملين بهيئـة مينـاء

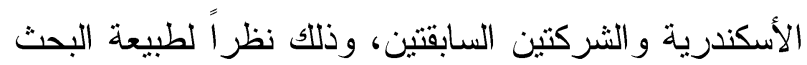

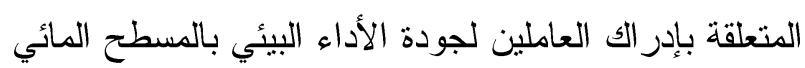

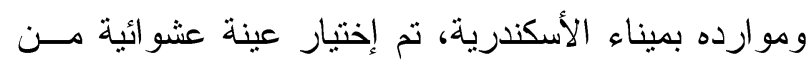

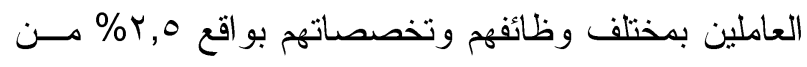

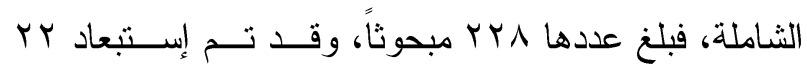

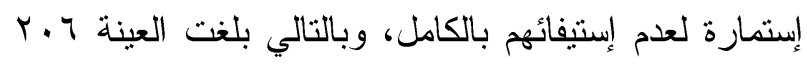
مبحوث، من إجمالي شاملة بلغت هب إلو 9 عامل. 


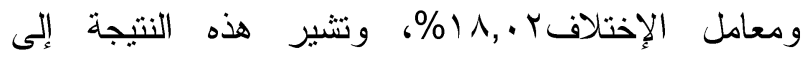

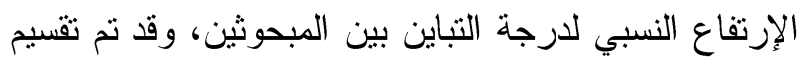

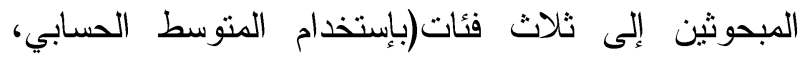
وطول فئة مقداره وحدة إنحر اف معياري)، وقد إنضح في التئي

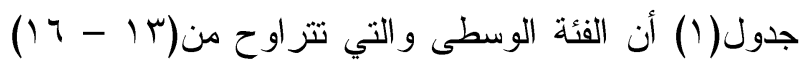
سنة تعليمية وهي أكبر الفئات حيث بلغت نسبتها المئوية

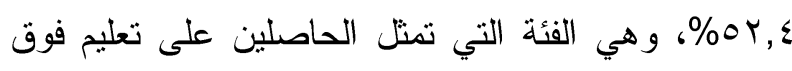
الكنوسط والتعليم الجامعي، وتثشير النتيجة إلى أن الميناء

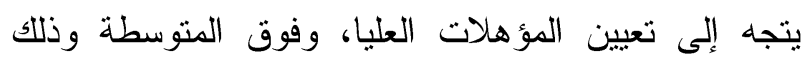
لأنهم حملة العلم ومنارة المستقبل.

\section{ع -المؤهل التعليمي للمبحوثين:}

تنشير النتائج البحثية في جدول(1) إلى أن الغالبية العظىى للمبحوثين كانو ا من حملة المؤهلات الجامعية حيث الميث

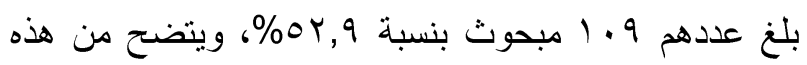

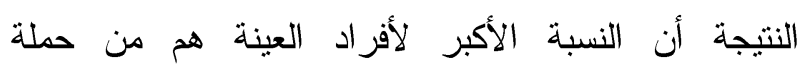

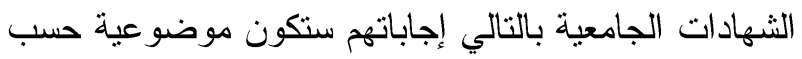

$$
\text { خبرتهم العلمية. }
$$

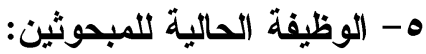

تثير النتائج البحثية في جدول(1) إلى أن الغالبية العظمى للمبحوثين كانوا من أصحاب الوظائف التنفيذية،

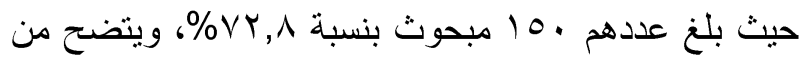

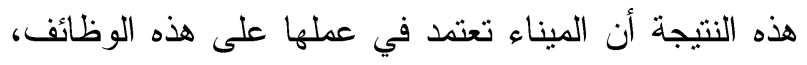
وذلك لتباين الأعمال بداخلها و لأنشطتها المتباينة. צ- عدد سنوات الخبرة للمبحوثين:

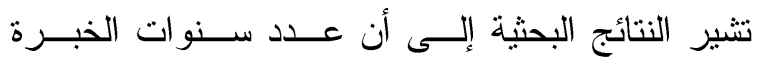

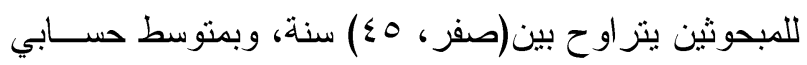

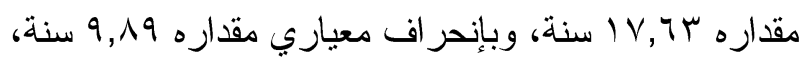

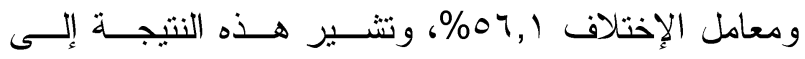
الإرتفاع الكبير في تباين عدد سنوات الخبرة بين المبحوثين، وقد تم تقسيم المبحوثين إلى ثلاث فئات (بإستخدام المتوسط الحسابي، وطول فئة مقداره وحدة إنحر اف معياري)،
أدائهم البيئي بالمسطح المائي وموارده، وذللك علــى النحــو

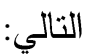
أولاً : بعض الخصائص المميزة للعاملين المبحوثين: يتم عرض ومناقثة لست سمات مميزة للمبحوثن بميناء الأسكندرية، وتشكل هذه السمات بعض الخصائص الميزة

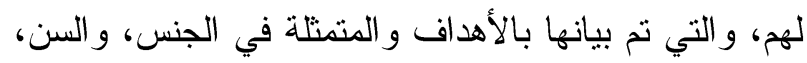

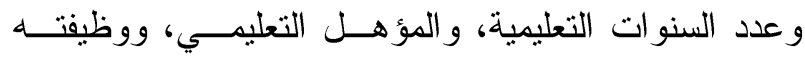

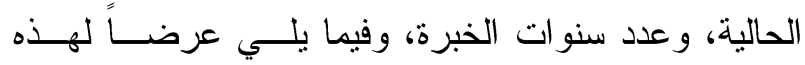

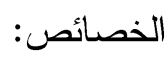

\section{1-جنس المبحوثين:}

تشير النتائج البحثية جدول(1) إلى أن الغالبية العظمى

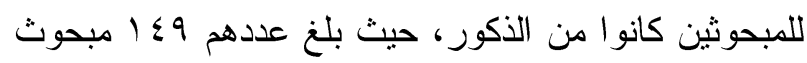

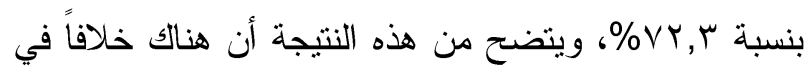

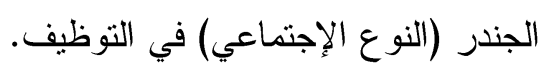

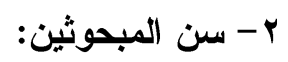

تشير النتائج البحثية إلى أن سن المبحوثين يتراوح بين

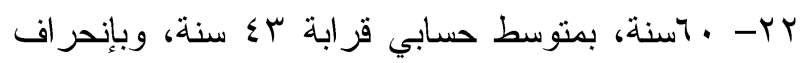

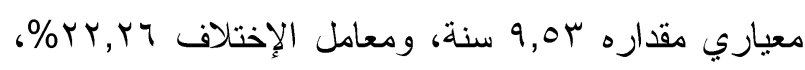

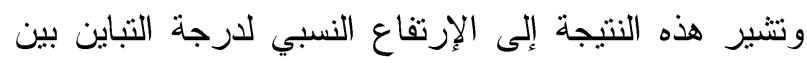

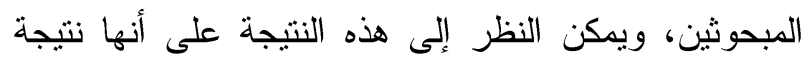
جيدة بإعتبار أن هناك جيل من الثباب يتصف بالكيدية و النشاط يتولى العمل داخل الميناء، وقد تم تقسيم المبحوثين

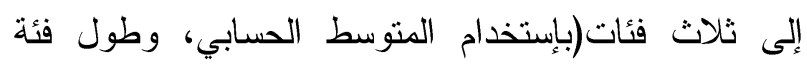

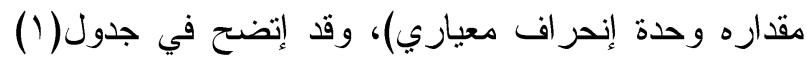

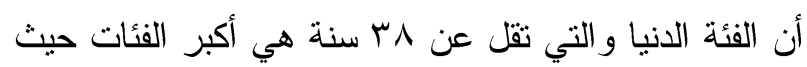

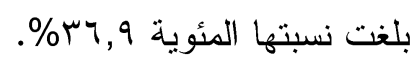
r- علد السنوات التعليمية للمبحوثين: تشير النتائج البحثية إلى أن عدد سنوات التعليم تتراوح

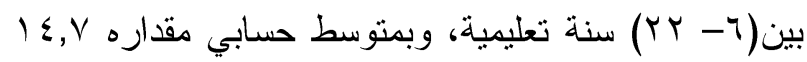
سنة تعليمية، وبإنحر اف معياري مقداره ب, r, سنة تعليمية، 
جدول r. توزيع المبحوثين وفقاً لتوجههم الإداري

\begin{tabular}{|c|c|c|c|c|c|}
\hline$\%$ & العدد & الفئات & $\%$ & العدد & الفئات \\
\hline & ارية: & r- الدرجة الكلية للقة & & & 1-التوجيه الإداري: \\
\hline$r ч, r$ & o \{ & الانبا (أقل من م1) & $r \cdot, \uparrow$ & זד & الدنبا (أقل من FoN) \\
\hline$\varepsilon \varepsilon, V$ & $9 r$ & الوسطي (10 - 7 - 1) & $\varepsilon r, V$ & $\wedge \wedge$ & الوسطي (به - 1 ا \\
\hline$r q, 1$ & 7. & العليا (أكثر من ؟ ـ 1) & $r ч, V$ & 00 & العليا (أكثر من ^ (س) \\
\hline $1 \ldots$ & $r \cdot T$ & المجموع الاع حة الاعلة للاد & $1 \ldots$ & $r \cdot T$ & 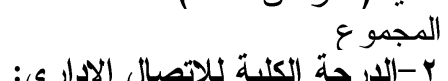 \\
\hline$r q, 7$ & 71 & الدنيا (أقل من V^) & 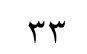 & $\uparrow \wedge$ & الدنيا (أقلْ من ״ \\
\hline$\varepsilon r, V$ & $\wedge \wedge$ & الوسطي ( V - . - . ) & $\varepsilon \cdot, \wedge$ & $\wedge \varepsilon$ & الوسطي (1) - ع 11) \\
\hline$r V, V$ & ov & العليا (أكثر من . 1) & $Y Y, Y$ & $0 \leqslant$ & العليا (أكثر من ع ( ) \\
\hline $1 \ldots$ & $r . Y$ & المجموع & $1 \ldots$ & 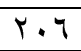 & المجموع \\
\hline
\end{tabular}

إنحراف معياري)، وقد إتضح في جدول(r) أن الفئة

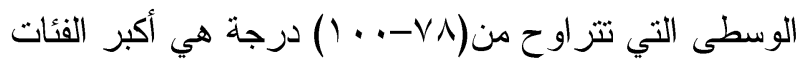

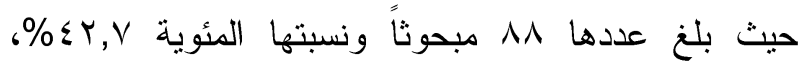
وتنثير النتيجة إلى أن هناك إنخفاض نسبي لنتوجه المبحوثين

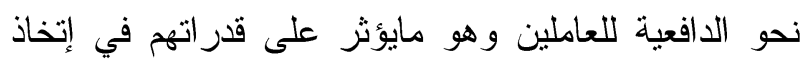
القرار و إنتمائهم للعمل ورضائهر عن بيئة العمل ورضائهر عن طبيعة العمل.

ثالثاً: المتغير التابع:

\section{إدراك العاملين لجودة الأداء البيئي:}

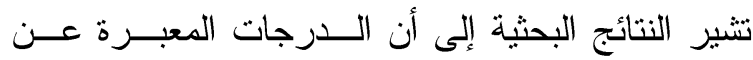

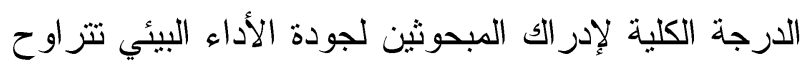

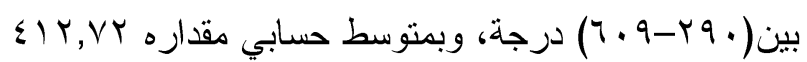

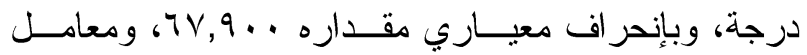

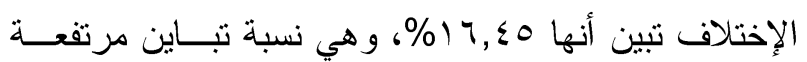

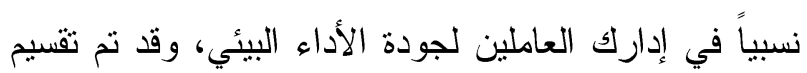
المبحوثين إلى ثلاث فئات(بإستخدام المتوســـ الحســابي، وطول فئة مقداره وحدة إنحر اف معياري)، وقد إنضح فـي

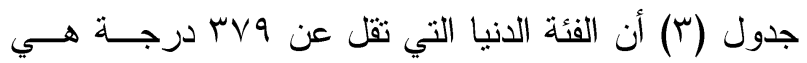

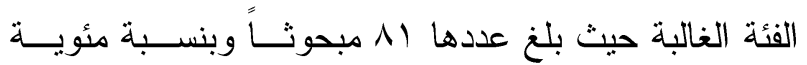
ץ,

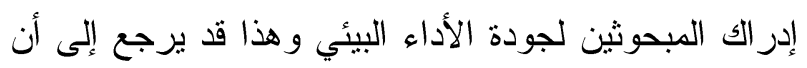

تنثير النتائج البحثية إلى أن الدرجات المعبرة عن توجه

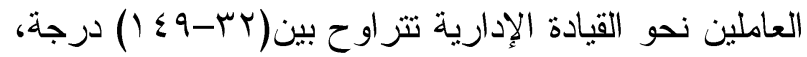
وبمتوسط حسابي مقداره 90,9 9 درجة، وبإنحر اف معياري

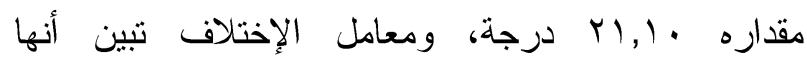
94,99 وهي نسبة مرتفعة نسبياً لدرجة التباين بين المبحوثين، وقد تم تقسيم المبحوثين إلى ثلاث فئات (بإستخدام المنوسط الحسابي، وطول فئة مقداره وحدة إنحراف معياري)، وقد إتضح في جدول(r) أن الفئة الفئة الوسطى التي تتزاوح من (10-7 • (1) درجة هي أكبر

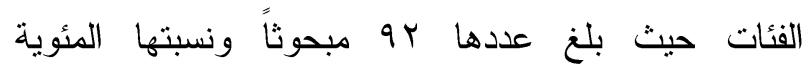
\%§,V الديمقر اطية داخل الميناء، ورضا نسبي للعاملين نحو القيادة

الإدارية التي يتبعونها.

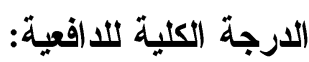

تثنبر النتائج البحثية إلى أن الدرجات المعبرة عن توجه

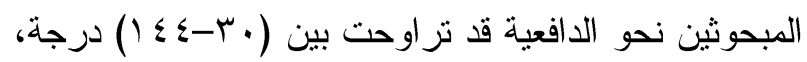
وبمتوسط حسابي مقداره ـ | (9 درجة، وبإنحر اف معياري

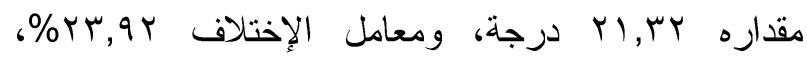

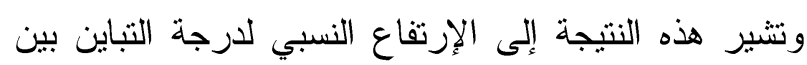

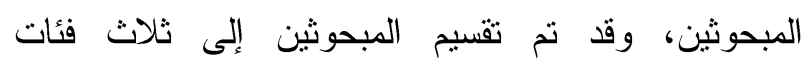

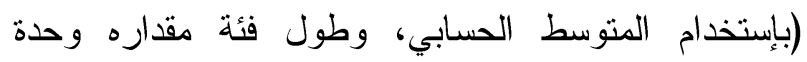




$$
\text { مجلة الإسكندرية للتبادل العلمى - (مجلدVT العدد ) أكتوبر - ديسمبر } 17 \text {. }
$$

العلاقات الإتحدارية بين المتغيرات المســتقة المدروســة، و الارجة الكلية لإدر الك العاملين لجودة الأداء البيئي: العلاقة الإحدارية بين التوجيه كمتغير مسـتقل والارجــة الكلية لإدر الك العاملين لجودة الأداء البيئي كمتغير تابع: بإستخدام أسلوب التحليل الإنحداري المتعــدد بطريقــة Stepwise، فقد أوضحت نتائج التحليل نموذج خطي للتحليل الإنحداري المتعدد، أثنمل النموذج الاول على متغير مستقل

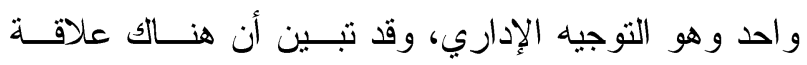

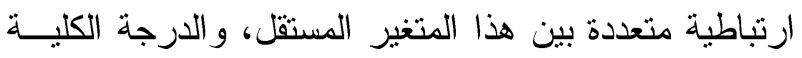

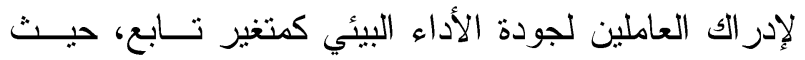

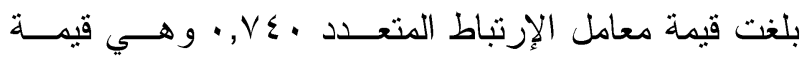
معنوية عند المستوى الإحتمالي ا +, · ميث بلغــت نســبة (ف) \& \& تفسير ^,ـ٪\% من التباين الكلي الممكن حدوثة في الدرجة

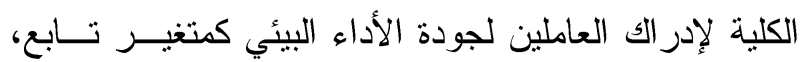
جدول(0).

وفي نفس الوقت توضتح النتائج الإحصـــائية أن قيمــة

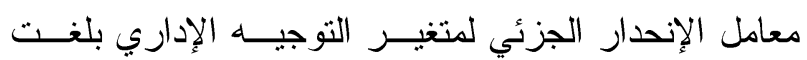

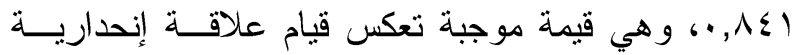
جزئية معنوية عند المستوى الإحتمالي ا +, +، حيث بلغــــ

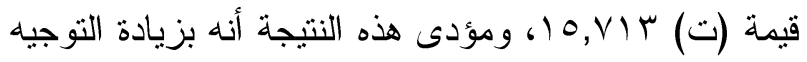
الإداري للمبحوث كمتغير مستقل بمقدار درجة واحدة تزداد الدرجة الكلية لإدر الك العاملين لجودة الأداء البيئي بمقــدار

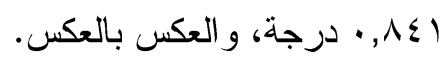

الفئة الغالبة للعمل داخل الميناء هم الثـــاب وأن خبــراتهم ماز الت منخفضة. جدول r. توزيع المبحوثين وفقاً لفئات الارجات الكلية لإدر اكهم لجودة الأداء البيئي

\begin{tabular}{|c|c|c|}
\hline$\%$ & العدد & الفئات \\
\hline$r q, r$ & $\wedge 1$ & الدنيا (أقل من rVq) \\
\hline rT, & 71 & الوسطي (rVq - \\
\hline$Y V, V$ & ov & العليا (أكثر من \& § \\
\hline $1 \ldots$ & $r \cdot T$ & المجموع \\
\hline
\end{tabular}

رابعاً: العلاقات الإرتباطية والإحدارية المتعددة بين كل من المتغيرات المستقلة المدروسة، والمتغير التابع: العلاقات الإرتباطية بين المتغيرات المســتقة المدروســـة، والارجة الكلية لإدر الك العاملين لجودة الأداء البيئي: أوضحت النتائج البحثية جدول(§) قيام علاقة إرتباطيــة معنوية عند المستوى الإحتمالي ا +, • بين كل من الإتصال

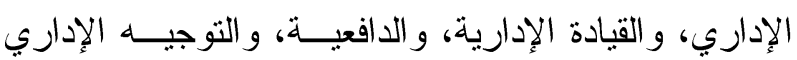

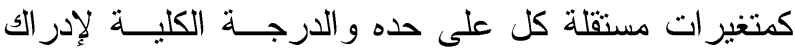
العاملين لجودة الأداء البيئي كمتغير تــابع، ومـــؤدى هــــه العلاقة أن المتغيرات المستقلة و المتغير التابع يتحركون في نفس الإتجاه. جدول \&. قيم معاملات الإرتباط بين كل مــن المتغيــرات المستقلة المدروسة والدرجة الكلية لإدرالك العاملين لجودة

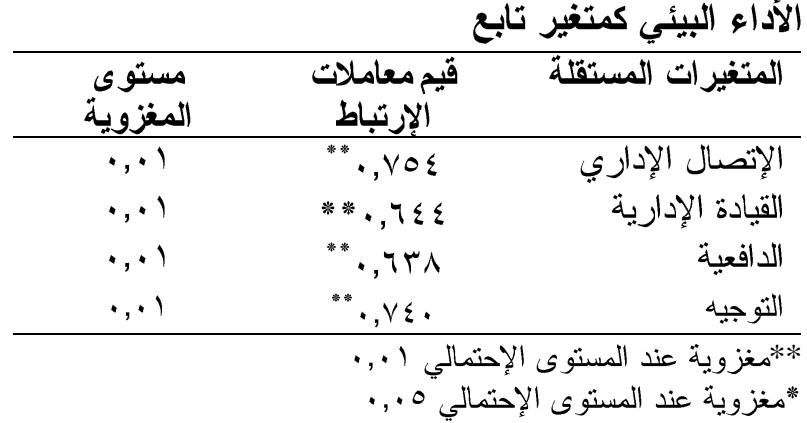

جدوله. العلاقة الإحدارية بين كل من التوجيه الإداري كمتغير مستقل والارجة الكلية لإدرالك العاملين لجودة الأداء البيئي

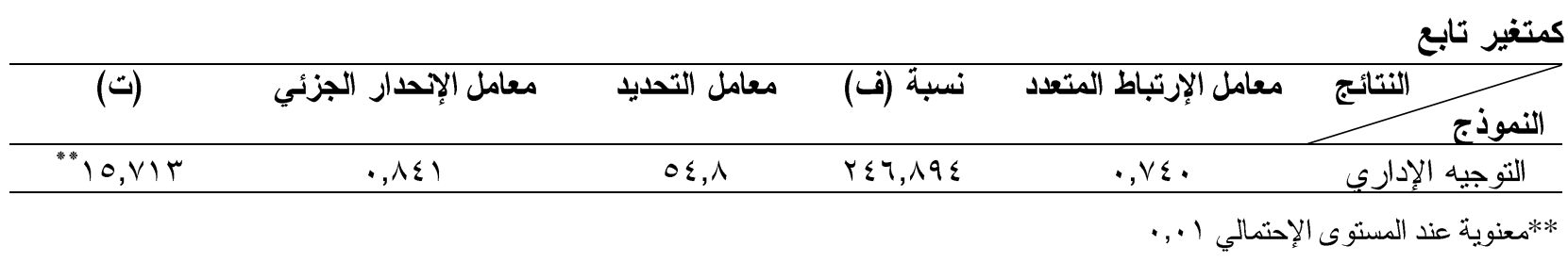


ظل ديناميكية التفاعل بين باقي المتغيرات المستقلة الداخلية في هذا النموذج. أما النموذج الإنحداري الثاني أثنــتمل علــى متغيــرين

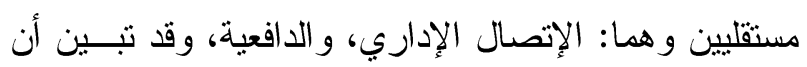
هناك علاقة إرتباطيــة متعـددة بـين هـــين المتغيـرين

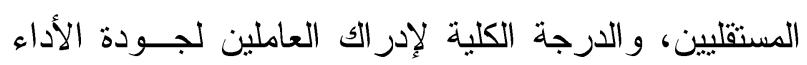
البيئي كمتغير تابع، حيث بلغت قيمة معامل الإرتباط المتعدد

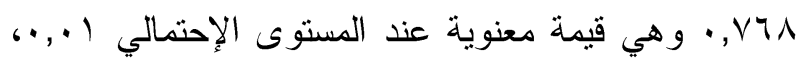

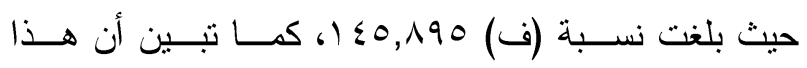
المتغيرين المستقلين مسئولين عن تفسير وه\% من التبـاين الكلي الممكن حدوثه في الدرجة الكليــة لإدر الك العـاملين

لجودة الأداء البيئي كمتغير تابع، جدول (T). وفي نفس الوقت نوضح النتائج الإحصـــائية أن قيمــة معامل الإنحدار الجزئي للمتغيـرين المســتقليين الإتصـــال

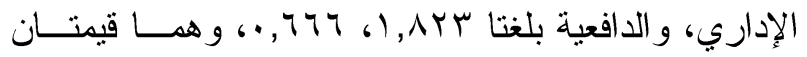
موجتان تعكسان قيام علاقتان إنحداريتان جزئيتان معنويتان

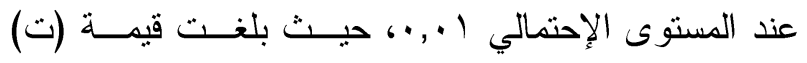

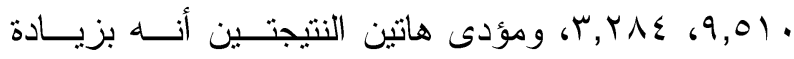
الإتصال الإداري، والدافعية للمبحوث كمتغيرين مســتقليين بمقدار درجة واحدة تزداد الدرجة الكلية لإدر الك العـاملين

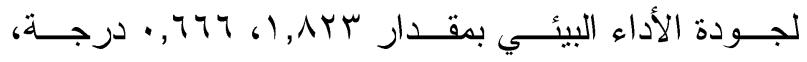
و العكس بالعكس، وذللك في ظل ديناميكية التفاعل بين باقي المتغير ات المستقلة الداخلية في هذا النموذج.
العلاقة الإحدارية بين الإتصال الإداري، والقيادة الإدارية، والدافعية كمتغيرات مستقلة والارجة الكلية لإدر الك العاملين لجودة الألداء البيئي كمتغير تابع: بإستخدام أسلوب التحليل الإنحداري المتعــدد بطريقــة

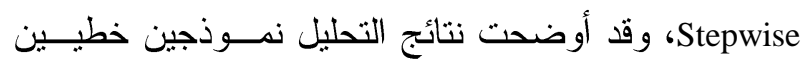
للتحليل الإنحداري المتعدد، أشتمل النمــوذج الاول علــى

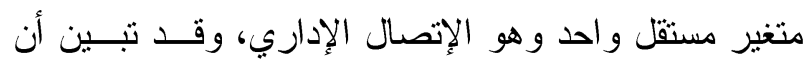

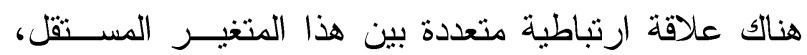
و الدرجة الكلية لإدر الك العاملين لجودة الأداء البيئي كمتغير

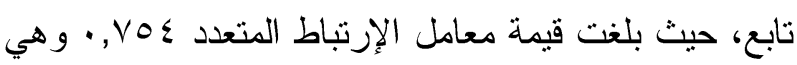

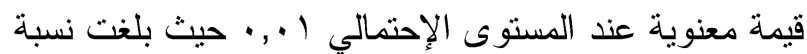

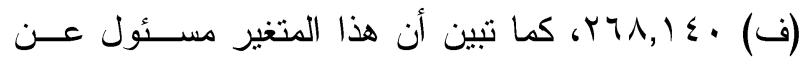
تفسير ^, ^0\% من التباين الكلي الممكن حدوثه في الدرجة

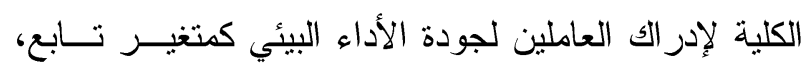
جدول (7).

وفي نفس الوقت توضتح النتائج الإحصــائية أن قيمــة معامل الإنحدار الجزئي لمتغير الإتصــال الإداري بلغــت

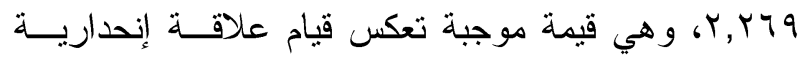

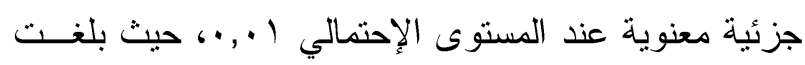

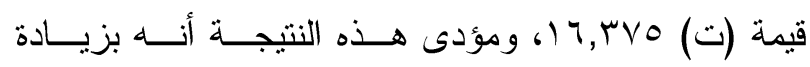

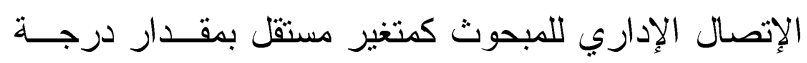
واحدة تزداد الدرجة الكلية لإدر الك العــاملين لجــودة الأداء البيئي بمقدار Y Y Y Y درجة، و العكس بالعكس، وذللك فــي

جدول جا. العلاقة الإحدارية بين كل من الإتصال الإداري، والقيادة الإدارية، والدافعية كمتغيرات مستقلة والارجــة الكليــة لإلدرالك العاملين لجودة الأداء البيئي كمتغير تابع

\begin{tabular}{|c|c|c|c|c|c|}
\hline (ت) & معامل الإِحدار & معامل التحديد & نسبة (ف) & معامل الإرتباط & النموذج \\
\hline$* * 1\rceil, r \vee 0$ & $Y, Y 79$ & 04,1 & YฯA, Is. & , , VO & نموذج (الإتصال الإداري \\
\hline $\begin{array}{l}* *^{*} 9,01 . \\
* T, Y \wedge \varepsilon\end{array}$ & $\begin{array}{l}1, \text { AYT } \\
., 7 Y Y\end{array}$ & 09 & $1 \leqslant 0, \wedge 90$ & $\cdot, \vee \vee \wedge$ & 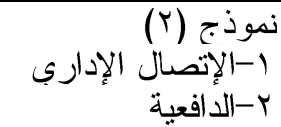 \\
\hline
\end{tabular}


- في ضوء إرتفاع معامل إختلاف الدرجة الكلية لإدر الك العاملين لجودة الأداء البيئي بالمسطح المائي وموارده إحهاء بين المبحوثني، بالإضافة إلى الإنخفاض النسبي في إدراكه، فإنه يوصى بأهمية تخطيط البرامج التدريبية

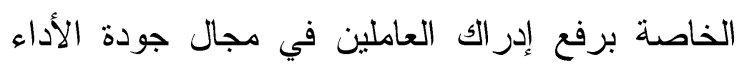
البيئي وكافة المجالات الأخرى المرتبطة بالبيئة، ورفع مستوى الجودة.

- يوصى بأهمية تتمية أبعاد إدراك العاملين لجودة الأداء البيئي بالمسطح المائي وموارده الستة لدى المبحوثين من حيث أكثرها تبايناً، وكذلك الأبعاد الأكثر إنخفاضاً فيما يتصل بدرجة إدرالك المبحوثين لها، وذلك في ضوء ما أتضح من تفاوت قيم معامل الأختلاف التي لإني تزاوحت من (9, (10, - 9,97)، ويوصى بإعداد

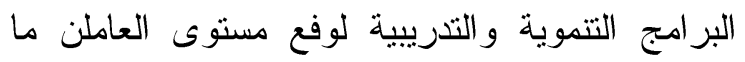
يضمن تحقيق تعظيم أدائهر.

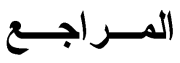

أرنوف ويتج ا . . ؟، ملخصات شوم نظريات ومسائل في مقدمة علم النفس، الدار الدولية للاستثمار ات الثقافية. ، بالبئ

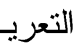

Available at :www.startimes.com/?t=30804013

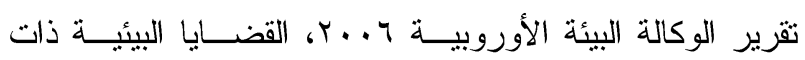
الأولوية في منطقة البحر المتوسط، الوكالة البيئية الأوروبية،

$$
\text { تقرير رقم (ع)، كوبنهاجن. }
$$

جهاز شئون البيئة، الفصل السادس: البيئة البحريــة و الســاحلية،

$$
\text { وزارة الدولة لنشئون البيئة، }
$$

Available at: www.yemen-nic.info/contents/Geog/6.pdf حسن إبر اهيم مكي، وآخرون 990 1، المدخل إلى علم الاتصال، منشور ات ذات السلاسل، الكويت.
التوقعات: - (التو

عمل دورات تدريبية منتظمة ومتخصصــة، وتســـيل إجراءات التخلص من جميع المخلفات، و إنشاء جهاز كفء للتفتيش على جميع أماكن العمل والآلات، وتطوير الكيـان

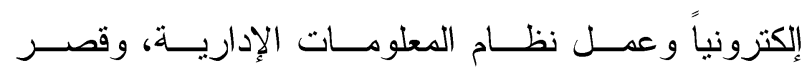

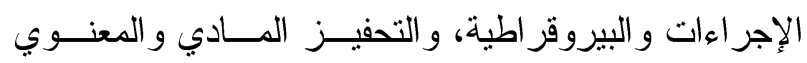

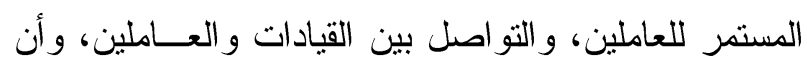

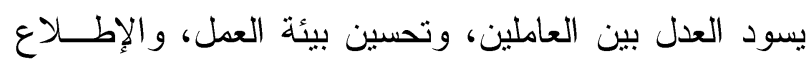
على تجارب الدول ذات الموانئ العالمية، و الإهتمام بنظــام الجودة وتفعيله، و الإهتمـــام بالســلامة و الصـــــة المهنيــة

$$
\text { للعاملين، و الإعتماد على الكفاءات الثابة. }
$$

- في ضوء ما اتضح من خصائص تتصل بالعاملين من

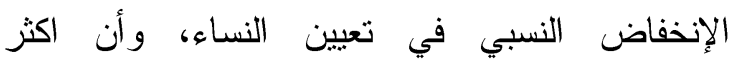
المبحوثين من الثباب، وأن المعظم كانوا من حملة المؤهلات العليا، وأن معظمهر من الوظائف التتفيذية، وأن الفئة الغالبة كانوا من ذوي الخبرات المنخفضة، وأهة فإنه يوصي بإعادة تأهيل وهيكلة أوضاع المبحوثين حتى يمكن ضمان أدائهم الذي يحقق الأهداف المرجوة

$$
\text { من العمل البيئي الإرشادي و الإدارة البيئية. }
$$

- في ضوء ما أتضح من إنخفاض درجات التوجيه الإداري للعاملين و أبعاده الثالثة التي تتمثل في الاتصال و القيادة و الدافعية، فإنه يوصى بإعادة هيكلة التنظيم الإداري

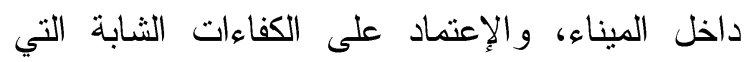
يمكن أن تدير المنشأة في المرحلة المقبلة وهي سوف تساهم في الإرتقاء.

- في ضوء ما أوضحته النتائج من أرتفاع تباين المبحوثين (إرتفاع قيمة معامل الإختلاف) فإنه يوصي بإعادة تأهيل المبحوثين بما يضمن تحقيق أكبر قدر ممكن من 
محمد بن دليم القحطاني ^ ^ . ب، إدارة الموارد البشرية نحو منهج

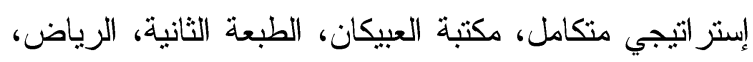
السعودية. محمد بن علي العقيفي .... ب، إدارة الجودة الثاملة في الموانئ

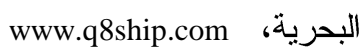

محمد عبد الغني حسن هلال 999 1، مهارات إدارة الجودة

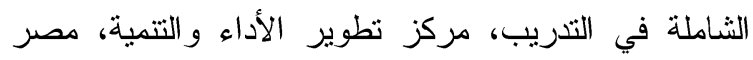

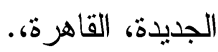

محمود المساد ץ. ..ץ، الإدارة الفعالة، مكتبة لبنان ناشرون، الطبعة الأولى، بيروت، لبنان.

نواف كنعان ب991، القيادة الإدارية، مكتبة دار التقافة للنشر

$$
\text { و التوزيع، الطبعة الأولى، عمان. }
$$

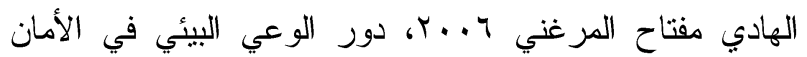
المهني لدى العاملين بالموانئ (دراسة مقارنة بين مينائي

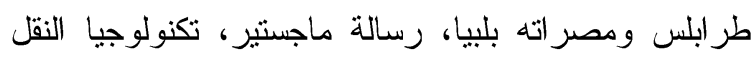

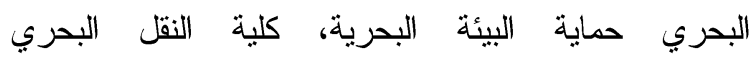
و التكنولوجيا، الأكاديمية العربية للعلوم و التكنولوجيا و النقل

$$
\text { البحري، الأسكندرية. }
$$

وزارة الدولة لنشئون البيئة . . •r، الخطوط الإرشادية لتطبيق

$$
\text { نظام الإدارة البيئية بالموانئ البحرية، البهاه }
$$

Available at: www.eeaa.gov.eg

El-Mamony, Mohamed -H, and Laila A. Mohamed, 2006 Concentration of some heavy metals in short cores in the near shore sediments of Alexandria, Egypt ،Qatar univ. Sci. J., vol 26, Pp. $101-112$
سعد غانم النعيمي، دور العنصر البشري في تحقيق السلامة فـي

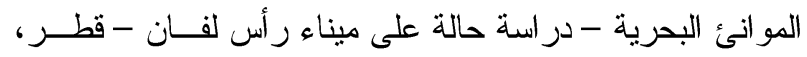

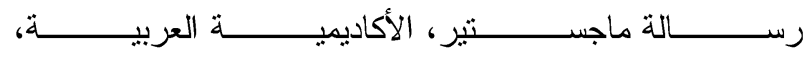
Available at: www.mubasher.info/news/2392929

سيكولوجية الدافعية، Available at: www.onefd.edu.dz/infpe/cours\%20pdf\%201 mef/...pdf/Psy cho\%20env1\%20def03.pd

ظريف شوقي ب99 19، السلوك القيادي وفعاليـــة الإدارة، مكتبــة غريب، القاهرة.

فريد كورنل، و آخرون ب ا • Y، الجودة و أنظمة الآيــزو، كنــوز المعرفة، الطبعة الأولى، عمان، الأردن.

قطاع النقل البحري، وزارة النقل جمهوريـــة مصــر العربيــة، \#/Available at: http://www.mts.gov.eg

كريمة بورحلي 2010، التلوث البحري وتأثيره على البحارة در اسة ميدانية بميناء الصيد )بوديس (جيجل، رسالة ماجستير ، قسم علم الإجتماع، كلية العلوم الإنسانية والعلوم الإجتماعية، جامعة منتوري، قسطنطنية، الجمهورية الجزية الائرية الديمقر اطية الشعبية.

اللجنة الاقتصادية والاجتماعية لغربي آسيا V ... r، الممارسات الجيدة في تطبيق تكنولوجيا المعلومات والاتصالات في الموانئ البحرية في البلدان الأعضاء في الأسكوا، الأمم المتحدة.

محمد أحمد صقر يناير 990 1، دور الموانئ في النقل والتجارة و اللوجيستيات، مجلة الأكاديمية العربية للعلوم و التكنولوجيا و النقل البحري، مجلد (•r)، العدد (q⿳)، الأسكندرية. 


$$
\text { مجلة الإسكندرية للتبادل العلمى - (مجلد Tr العددء) أكتوبر - ديسمبر } 17 \text {. }
$$

\title{
ABSTRACT \\ Effect of the Administrative Guidance on the Employees' Perception of the Environmental Performance Quality of Water Body and its Resources in Alexandria Port
}

\author{
Mahmoud T. Shaaban, Ebtessam E. El-Sayed, Ashour K. Ashour, Hoda A. Mohamed, \\ Noura H. Saad Hassan
}

This research aimed mainly the effect of the administrative guidance on the employees' perception of the environmental performance quality of water body and its resources in Alexandria port, this aim could be achieved through the study of a group of sub- objectives.

A well prepared and pretested questionnaire were used to collect data needed for this research. Data was gathered from a sample, consisted of (206) respondents. Data was analyzed statistically by using SPSS program. Percentage, average, standard deviation, person's correlation and multiple correlation coefficient, partial and multiple - regression, $\mathrm{t}$ (test), $\mathrm{F}$ ratio were used to analysis the data.

The averages of the nature and characteristics of respondents were in middle category, with the high variance between the total degrees of respondents.

The total degree of the respondents employees' perception of the environmental performance quality of water body and its resources in Alexandria port: research results showed an average of (412.72) degrees and standard deviation of (67.900) degrees.

The total degree of the respondents administrative guidance: research results showed an average of (287.745) degrees and standard deviation of (59.73) degrees.

Research results revealed that there was a significant positive relationship at the level of probability 0.01 between each of the total degree of the respondents administrative guidance and the total degree of the respondents employees' perception of the environmental performance quality of water body and its resources in Alexandria port as the dependant variable.

Research results showed that one equation of multiple regression relationships, the model indicted the directive responsible for the interpretation of $54.8 \%$ of the variation possible it happens in total degree of the respondents employees' perception of the environmental performance quality of water body and its resources in Alexandria port as the dependant variable, and this equation is significant at the level of probability 0.01 . 